\title{
Corporate Governance, Executive Directors and Level of Voluntary Disclosure: The Case of Public Listed Companies in Thailand
}

\author{
JAKKRAVUDHI CHOBPICHIEN \\ Faculty of Management Science \\ Suan Dusit Rajabhat University \\ DAING NASIR IBRAHIM \\ HASNAH HARON \\ School of Management \\ Universiti Sains Malaysia
}

\begin{abstract}
This paper extends the literature on voluntary disclosure by reference to a developing country, namely Thailand, through a study of 70 voluntary disclosure items in the corporate annual reports of 317 public listed companies in 2004. The study examined the relationship between the level of voluntary disclosure and a single characteristic of corporate governance characteristics, namely the quality of the board of directors. It further examined the influence of the executive directors on this relationship. The findings suggested that the quality of the board of directors is positively associated with the level of voluntary disclosure, and this association appears to be weaker for firms with an executive director that has the family member, largest shareholder involved compared to the non-family member, largest shareholder and a high concentration of executive directors' ownership compared to a low concentration of executive directors' ownership. This effect is further exacerbated when board of directors' quality levels increase. It was found that an executive director that has the family member, largest shareholder involved, and a high concentration of executive directors' ownership are quasi moderators, which means they are both an independent and a moderating variable. As control variables, size of company, auditor type, and earnings return were found to have a significant influence on the level of voluntary disclosure. These results have important implications for good corporate governance policy formulation.
\end{abstract}

Keywords: Corporate governance; executive directors; firm characteristics; voluntary disclosure; stock exchange of Thailand.

\section{INTRODUCTION}

Disclosure by firm managers represents an opportunity to reduce the information asymmetry that exists between firm managers and investors. This is because there exist a negative relationship between the disclosure levels of the companies and information asymmetry. The incentive to disclose in annual reports is that firm managers can reduce investors' concern as to whether the management is acting in their best interests. Annual reports provide a means for the management to convince 
investors that they are optimising shareholders' wealth. In fact, managers may choose to disclose more than is mandated by corporate law. Such disclosure is termed voluntary disclosure; the greater the disclosure by companies in the annual reports, the greater the transparency (Balachandran \& Bliss, 2004).

Transparency and adequate disclosure are also important in order to ensure the protection of minority shareholders' rights. Outsiders can use relevant company information, such as company objectives and policies, financial results, majority shareholder ownership structure, and executive directors' remuneration to make decisions. The adoption of internationally accepted disclosures (sometimes voluntary in Thailand) represents free choice on the part of company management to provide accounting and other information deemed relevant to the decision needs of the users of their annual reports (Meek, Roberts, \& Grey, 1995). In addition, in a study by Toplin, Tower, and Hancook (2002), 60 annual reports from companies in Australia, Hong Kong, Malaysia, Philippines, Singapore, and Thailand were analysed to create several compliance indices based on all universally applicable IAS rules at the time. The companies in the four Asian countries with British colonial links had lower levels of non-disclosure than Philippines or Thailand. However, the problem of voluntary disclosure in Thailand comes from a study by the Center for International Financial Analysis and Research (CIFAR, 1995). There is a perception that the adequacy in voluntary disclosure in Emerging Capital Markets, including Thai public listed companies, was in the bottom half in terms of disclosure levels, and lags behind that in developed capital markets. Companies in Asia appear to have fewer incentives for transparent disclosure than their Anglo-American counterparts (Ball, Robin, $\& \mathrm{Wu}, 2003)$. This is probably due to the fact that the disclosure orientation of companies in Asian countries is significantly influenced by the cultural environment in which they operate (Gray, 1988).

The disclosure orientation of companies in Thailand is also greatly influenced by the form of ownership and management structure (Limpaphayom, 2000). Thai listed companies are usually controlled by a family group whose staff are in senior positions and who also function as the largest shareholder. Thai ownership is highly concentrated and most of the shares are owned by executive directors. As a result, managers and owners are the same person (Wiwattanakantang, 2000).

An important mechanism in protecting shareholders is the board of directors and its fiduciary responsibilities. This is because the board of directors is supposed to monitor managers and control the companies on behalf of the shareholders. The board is expected to formulate corporate policy, approve strategic plans, and, if necessary, remove management. However, the board of directors of most listed companies in Thailand is mostly controlled by large shareholders (Limpaphayom, 2000).

Ownership concentration has been a key player driving the Thai economic boom since the late 1950s. This economic prosperity was characterised by the emergence of family business groups which became an important constituent in the business community through the government's promotion policies and infusion of foreign capital, as well as through their own entrepreneurial skills. The groups later formed 'business conglomerates', embracing between 15 to 90 associated firms per group, and had oligopolistic status in various industries such as finance, import substitution, and agro industry (Suehiro, 1989). The pattern of family business persisted even after the firms were listed in the Stock Exchange of Thailand (SET), where neither foreign ownership nor state ownership has ever been prominent since the SET was established in 1975 (Dhnadirek \& Tang, 2003). Thai listed firms preferred debt financing, usually from banks, because they did not have to worry about the effects of ownership dilution which may be incurred through equity financing (Endo, Griffiths, Haskar, Schwartz, Barnett \& Lee, 2000). Furthermore, in industries like finance and insurance, banks were at the centre of the business group and used their capital to finance all the firms in the group (Suehiro, 1989). Family members were often insiders, meaning that they were major shareholders, managers, and members of the board of directors, as well as the ones who nominated outside directors. The role of outside 
directors per se is minimal; usually only two persons are nominated to the board committee simply to fulfill the requirement of the Securities and Exchange Commission (SEC). Furthermore, as firm ownership was dominated by inside shareholders, the outside shareholders (those who did not hold management positions in the firm) would find it difficult to garner sufficient votes to influence or oust incumbent management hence, restricting the role of the market in corporate control (Limpaphayom, 2000). Such unique environments in Thailand provide an opportunity to examine empirically the effect of ownership on the relationship of board of directors' quality and voluntary disclosure.

Some studies have examined corporate governance characteristics that may influence voluntary disclosure practice (Balachandran \& Bliss, 2004; Chau \& Gray, 2002; Chen \& Jaggi, 2000; Evans, 2004; Forker, 1992; Gul \& Leung, 2004; Haniffa \& Cooke, 2002; Ho \& Wong, 2001; Hope, 2003; Liu, 2004; Mangena \& Pike, 2005; McKinnon \& Dalimunthe, 1993; Mohd-Nasir \& Abdullah, 2005; Willekens, Vander Bauwhede, Gaeremynck \& Van de Gucht, 2004). However, they examined the effect of various corporate governance characteristics and very few have actually examined the effect of a set of the corporate governance characteristics.

The main objective of this study was to examine the relationship between each dimension and the level of the board of directors' (BOD) quality and the extent of voluntary disclosure of listed companies in Thailand. The other objective of the study was to investigate whether managerial ownership affects the relationship between each dimension and the level of the (BOD) quality and the level of voluntary disclosure. Under the implicit assumption of positive agency theory, this study hypothesised that improved BOD and managerial ownership of Thai public listed companies lead to more voluntary disclosure practices and the voluntary disclosure practices are used as a means to reduce information asymmetry and agency problems.
However, the findings in Thailand can be generalised to other countries or economies with similar institutional backgrounds as Emerging Capital Markets (ECM) is understood to mean a stock market located in a developing country. At present, there are 47 countries whose capital markets are considered ECMs by the International Finance Corporation (IFC, 1994; Saudagaran \& Diga, 1997); 14 countries are in Africa, i.e. Botswana, Cote d'Ivoire, Cyprus, Egypt, Ghana, Kenya, Mauritius, Namibia, Nigeria, South Africa, Swaziland, Trinidad and Tobago, Tunisia, and Zimbabwe; 11 countries are in Asia, i.e. Bangladesh, China, India, Indonesia, Korea, Malaysia, Pakistan, Philippines, Sri Lanka, Taiwan, and Thailand; five countries are in Europe i.e. Greece, Hungary, Poland, Portugal, and Turkey; 13 countries are in Latin America, i.e. Argentina, Barbados, Brazil, Chile, Colombia, Costa Rica, Ecuador, Jamaica, Mexico, Panama, Peru, Uruguay, and Venezuela; and four countries are in the Middle East, i.e. Iran, Jordan, Morocco, and Oman.

The rest of this paper is organised as follows. Section 2 reviews the related literature and proposes hypotheses being tested. Section 3 discusses the data and sample design. Section 4 presents the empirical results and discussion, and section 5 presents a summary and conclusions.

\section{LITERATURE REVIEWS AND HYPOTHESES DEVELOPMENT}

\section{Positive Agency Theory as Theoretical Explanations for the Relationship between Corporate Governance Mechanisms and Voluntary Disclosure}

Under the implicit assumption of Jensen and Meckling's (1976) positive agency theory, the study hypothesised that an improved quality of the BOD would lead to more voluntary disclosure practices, and that voluntary disclosure practices 
are used as a means to reduce information asymmetry and agency problems.

Leftwich, Watts and Zimmerman (1981) argued that the larger the proportion of independent directors on the board, the more effective it will be in monitoring managerial opportunism, and thus firms whose boards are dominated by outside directors are expected to disclose more voluntary information. This contention is supported by the study conducted by Forker (1992) who found that a higher proportion of independent non-executive directors should enhance the quality of information disclosed and reduce the benefits of withholding.

Fama and Jensen (1983a) found that a higher proportion of independent nonexecutive directors on the board should result in more voluntary corporate disclosure. They had suggested that once the firm's capital is widely held, the potential of conflicts between principal and agent is greater than in familycontrolled firms. To reduce these conflicts, some shareholders especially institutional ones have forced managers to disclose more corporate information for the accurate evaluation of the firm's performance. As a result, information disclosure is likely to be more intensive in widely held firms. The prevalence of family-controlled firms listed on a stock exchange, which is the case in the SET, may result in less demand for corporate disclosures (Dhnadirek \& Tang, 2003). Furthermore, Wiwattanakantang (2000) found that Thai listed companies' ownership is highly concentrated and most of the shares are owned by executive directors. As a result, managers and owners are one and the same person. When, ownership is highly concentrated, the nature of the agency problem shifts away from managershareholder conflicts to conflicts between the controlling owner and minority shareholders (Berle \& Means, 1932; Fan \& Wong, 2002, Hope, 2003). Consequently, Chau and Gray
(2002) argued when the ownership structure is concentrated, large institutional investors may be less concerned with voluntary disclosure, given that they have access to the information from the insider. They found that prevalence of insiders and family-controlled firms is associated with low levels of voluntary disclosures.

Jensen (1993) argued that board composition and board leadership structure are associated with the board monitoring incentives. It was posited that board composition and board leadership structure are associated with voluntary disclosure.

Ho and Wong (2001) indicated that the independence of the audit committee has also been found to be a determinant of the level of voluntary disclosure and the percentage of family members on the board does affect the level of voluntary disclosure.

In addition, Eng and Mak (2003) showed that lower managerial ownership and significant government ownership are associated with higher voluntary disclosure.

Willekens et al. (2004) found that governance mechanisms introduced by companies can increase the disclosure of both financial and non-financial information. The disclosure of this information will assist to reduce information asymmetry and agency problems (Balachandran \& Bliss, 2004).

\section{Ownership Structure as Moderator Variables}

There are many reasons for the study of ownership structure as moderator variables in Thailand. For the first reason, the most recent research posited that ownership structure and BOD characteristics as independent variables affect disclosure (Eng \& Mak, 2003; Evans, 2004; Forker, 1992; Haniffa \& Cooke, 2002; Mangena \& Pike, 2005; Mohd-Nasir \& Abdullah, 2005).

Table 1 summarises literature relating BOD characteristics and ownership structure to corporate disclosure. 
Table 1: Summary of Literature Relating Board of Directors' Characteristics and Ownership Structure to Corporate Disclosure

\begin{tabular}{|c|c|c|c|c|}
\hline \multirow[t]{3}{*}{ No. } & \multirow{3}{*}{$\begin{array}{c}\text { Previous studies } \\
\text { Author(s) } \\
\end{array}$} & \multicolumn{2}{|c|}{ Independent Variable Items } & \multirow{3}{*}{$\begin{array}{c}\text { Dependent } \\
\text { Variable } \\
\end{array}$} \\
\hline & & \multicolumn{2}{|c|}{ Results (Significant unless otherwise stated) } & \\
\hline & & Board of Directors & Ownership Structure & \\
\hline 1 & $\begin{array}{l}\text { Eng and Mak } \\
\text { (2003) }\end{array}$ & $\begin{array}{l}\text { 1. Proportion of outside } \\
\text { directors on the } \\
\text { board }(+)\end{array}$ & $\begin{array}{l}\text { 1. Managerial ownership (-) } \\
\text { 2. Existence of government } \\
\text { ownership (+) } \\
\text { 3. Government ownership } \\
\text { (+) } \\
\text { 4. Blockholder ownership } \\
\text { (- and not significant) }\end{array}$ & Voluntary Disclosure \\
\hline 2 & $\begin{array}{l}\text { Evans } \\
(2004)\end{array}$ & $\begin{array}{l}\text { 1. Board } \\
\text { independence (+ } \\
\text { and not } \\
\text { significant) } \\
\text { 2. AC independence } \\
\text { (+ and not } \\
\text { significant) } \\
\text { 3. CEO-Chairman } \\
\text { separation (+ and } \\
\text { not significant) } \\
\text { 4. Number of board } \\
\text { meetings (+ and } \\
\text { not significant) } \\
\text { 5. AC meetings (+ } \\
\text { and not } \\
\text { significant) }\end{array}$ & $\begin{array}{l}\text { 1. Extent of managerial } \\
\text { ownership (- and not } \\
\text { significant) } \\
\text { 2. Extent of institutional } \\
\text { ownership (+ and not } \\
\text { significant) }\end{array}$ & Disclosure Quality \\
\hline 3 & $\begin{array}{l}\text { Forker } \\
(1992)\end{array}$ & $\begin{array}{l}\text { 1. CEO duality (-) } \\
\text { 2. Proportion of } \\
\text { Independent non- } \\
\text { executive directors } \\
\text { on the board (+ } \\
\text { and not } \\
\text { significant) } \\
\text { 3. Existence of AC (+ } \\
\text { and not } \\
\text { significant) }\end{array}$ & $\begin{array}{l}\text { 1. Proportion of the firm } \\
\text { owned by management } \\
\text { (- and not significant) }\end{array}$ & $\begin{array}{c}\text { Share Options } \\
\text { Disclosure }\end{array}$ \\
\hline 4 & $\begin{array}{c}\text { Haniffa and } \\
\text { Cooke (2002) }\end{array}$ & $\begin{array}{l}\text { 1. CEO duality (- and } \\
\text { not significant) } \\
\text { 2. Proportion of } \\
\text { Independent non- } \\
\text { executive directors } \\
\text { on the board (+ } \\
\text { and not } \\
\text { significant) } \\
\text { 3. Chairman is non- } \\
\text { executive director } \\
(-) \\
\text { 4. Family members } \\
\text { on the board (-) }\end{array}$ & $\begin{array}{l}\text { 1. Ratio of total shares } \\
\text { owned by top ten } \\
\text { shareholders }(+) \\
\text { 2. Ratio of total shares } \\
\text { owned by foreign } \\
\text { investors (+) } \\
\text { 3. Ratio of total shares } \\
\text { owned by institutional } \\
\text { investors (+ and not } \\
\text { significant) }\end{array}$ & Voluntary Disclosure \\
\hline
\end{tabular}


(continued)

\begin{tabular}{|c|c|c|c|c|}
\hline 5 & $\begin{array}{l}\text { Mangena and } \\
\text { Pike (2005) }\end{array}$ & $\begin{array}{l}\text { 1. AC member is a } \\
\text { financial expert }(+) \\
\text { 2. Proportion of non- } \\
\text { executive directors } \\
\text { (+ and not } \\
\text { significant) }\end{array}$ & $\begin{array}{l}\text { 1. Percentage of shares } \\
\text { owned by AC (-) } \\
\text { 2. Percentage of shares held } \\
\text { by institutional } \\
\text { shareholders }(+) \\
\text { 3. Percentage of shares } \\
\text { owned by executive } \\
\text { directors (- and not } \\
\text { significant) }\end{array}$ & $\begin{array}{l}\text { Interim Financial } \\
\text { Disclosure }\end{array}$ \\
\hline 6 & $\begin{array}{l}\text { Mohd-Nasir and } \\
\text { Abdullah } \\
(2005)\end{array}$ & $\begin{array}{l}\text { 1. Proportion of } \\
\text { Independent non- } \\
\text { executive directors } \\
\text { on the board (+) } \\
\text { 2. Proportion of } \\
\text { Independent non- } \\
\text { executive directors } \\
\text { on the AC (+ and } \\
\text { not significant) }\end{array}$ & $\begin{array}{l}\text { 1. Equity owned by outside } \\
\text { blockholding (+) } \\
\text { 2. Equity owned by } \\
\text { management ownership } \\
(+) \\
\text { 3. Equity owned by non- } \\
\text { executive directors (+ } \\
\text { and not significant) }\end{array}$ & Voluntary Disclosure \\
\hline
\end{tabular}

From Table 1 it can be seen that most previous studies used BOD characteristics and ownership structure as independent variables. There have been conflicting results in previous studies. It was believed that the treatment of ownership structure as an independent variable has caused these mixed results. Thus this study would like to suggest the use of ownership structure as a moderating variable. Other reasons to support this is discussed below.

It is difficult or expensive for the minority shareholders to verify what the family controlling ownership is actually doing with independent directors. Thus, the theoretical contribution of this study extends the positive agency theory to include ownership structure (i.e. family controlling ownership) as moderator variables.

The quality of BODs in the firms with family controlling ownership may become impaired and their influence on the disclosure quality of a firm's financial reporting may be weaker than in firms without family controlling ownership (Chen \& Jaggi, 2000; Forker, 1992).

The final reason, the board of directors is often seen as serving a monitoring function, protecting the interests of various stakeholders

against management's self-interests (Fama, 1980; Fama \& Jensen, 1983a). The boards with independent directors (Fama \& Jensen, 1983a), and those with the CEO's and chairperson's roles being separated (Jensen, 1993), had been argued by Mak and Roush (2000, p.147) "to be better able to monitor management". However, the study by Bathala and Rao (1995) found a negative significant relationship between board ownership and the proportion of outside directors on the board. In addition, Mak and Roush (2000) found that the proportion of outside directors is negatively related to inside share ownership. Consequently, Mak and Li (2001) found that the proportion of outside directors is negatively related to managerial ownership and a dual leadership structure is positively related to blockholder ownership.

Thus, managerial controlling ownership is likely to be influenced by a close relationship with outside directors in the hope that they would be in support for the management's philosophy and policies. Consequently, in the presence of managerial controlling ownership, outside directors' independence may be compromised. Thus, the theoretical contribution of this study 
extends the positive agency theory to include ownership structure as moderator variables (Chen \& Jaggi, 2000; Forker, 1992).

\section{Firm Characteristics as Control Variables}

There has been extensive empirical work relating firm-specific characteristics to the extent of voluntary disclosure based on a number of theoretical arguments for structure-related characteristics which include agency theory, information and political costs, proprietary costs, and capital need such as debt-equity ratio (Hossain, Perera \& Rahman, 1995) and firm size (Cooke, 1989a; Haniffa \& Cooke, 2002; Hossain et al., 1995); performance-related characteristics which include legitimacy theory such as liquidity ratio (Hossain, Tan \& Adams 1994), support continuance and compensation such as rate of return (Singhvi \& Desai, 1971), and signaling theory such as profit margin (Singhvi \& Desai, 1971); and market-related characteristics which include capital need, foreign exchange listing requirements such as scope of business operations (Hossain et al., 1994), reputation costs and signaling agency costs such as audit firm size influence (Singhvi \& Desai, 1971).

In Thailand, there has been extensive empirical work relating firm-specific characteristics to the extent of voluntary disclosure, capital structure, and firm performance namely, structure-related characteristics for example, debt-equity ratio used by Priebjrivat (1992), SET (2001b), and Wiwattanakantang (1999); firm size used by Priebjrivat (1992), SET (2001b), Wiwattanakantang (1999), and Yammeesri and Lodh (2002). Performance-related characteristics for example, profit margin, earnings return, and liquidity ratio used by Wiwattanakantang (1999) and Yammeesri and Lodh (2002). Market-related characteristics for example, scope of business operations used by Wiwattanakantang (1999); audit size influence used by Priebjrivat (1992).
Thus, this study used firm-specific characteristics (i.e. structure-related characteristics such as debt-equity ratio and firm size; performance-related characteristics such as profit margin, earnings return, and liquidity ratio; and market-related characteristics such as scope of business operations and audit size influence) as control variables included in the model.

\section{Voluntary Disclosure Checklist}

Voluntary disclosure in accounting may be considered a complex function since it involves the relationships among institutions, companies, and individuals, and is also affected by culture and institutions. Leventis and Weetman (2000) argued that the theoretical and empirical literature has no principle certainty in the treatment of voluntary disclosures. In contrast, Meek et al. (1995) and Chau and Gray (2002) suggested that the voluntary disclosures should be divided into three categories: (1) strategic; (2) non-financial; and (3) financial. Therefore, the investors and stakeholders benefit from information disclosed in each category. For example, strategic and financial types of information have decision relevance to investors while non-financial information is directed toward a corporation's social accountability and targeted at a wider spectrum of stakeholders than owners/ investors (Chau \& Gray, 2002).

Table 2 reports the findings of voluntary disclosure of Meek et al. (1995) and Chau and Gray (2002) in accordance to these three categories. These studies also report the "overall mean" of the voluntary disclosure.

It is difficult to compare the studies conducted by these two previous researchers. As can be seen from Table 2, the two researchers have looked at these three categories that can be usefully adopted in other studies. In fact all three categories are appropriate if one were to examine voluntary disclosure in Thailand. 
Table 2: The Level of Voluntary Disclosure in the Three Categories and Overall Disclosures

\begin{tabular}{|c|c|c|c|c|c|c|c|c|}
\hline \multirow{2}{*}{ Information: } & \multicolumn{2}{|c|}{ Strategic } & \multicolumn{2}{|c|}{ Non-financial } & \multicolumn{2}{|c|}{ Financial } & \multicolumn{2}{|c|}{ Overall } \\
\hline & Mean \% & SD & Mean \% & SD & Mean \% & SD & Mean \% & $\mathrm{SD}$ \\
\hline \multicolumn{9}{|l|}{ Meek et al. (1995) } \\
\hline All companies & 21.03 & 13.81 & 18.06 & 11.01 & 16.62 & 8.89 & 18.23 & 7.49 \\
\hline All USA & 17.22 & 10.52 & 11.89 & 7.10 & 16.54 & 6.81 & 15.20 & 5.40 \\
\hline International USA & 20.03 & 10.98 & 14.50 & 7.41 & 17.27 & 7.12 & 17.09 & 5.55 \\
\hline Domestic USA & 14.41 & 9.32 & 9.27 & 5.73 & 15.81 & 6.46 & 13.32 & 4.56 \\
\hline All UK & 16.83 & 8.52 & 25.70 & 9.15 & 14.58 & 9.30 & 18.73 & 6.78 \\
\hline International UK & 17.41 & 9.70 & 25.71 & 10.28 & 16.92 & 10.44 & 19.87 & 7.95 \\
\hline Domestic UK & 16.24 & 7.27 & 25.69 & 8.03 & 12.24 & 7.44 & 17.60 & 5.24 \\
\hline All Europe & 36.52 & 16.56 & 23.01 & 12.41 & 19.67 & 11.83 & 25.16 & 8.30 \\
\hline International Europe & 36.51 & 17.54 & 21.87 & 13.28 & 23.19 & 9.34 & 26.23 & 8.36 \\
\hline Domestic Europe & 36.53 & 15.05 & 24.16 & 11.65 & 16.15 & 13.16 & 24.09 & 8.29 \\
\hline \multicolumn{9}{|l|}{ Chau and Gray (2002) } \\
\hline Hong Kong & 18.49 & 9.90 & 10.45 & 5.11 & 9.77 & 8.37 & 12.23 & 7.74 \\
\hline Singapore & 16.00 & 9.00 & 16.76 & 9.69 & 10.68 & 6.93 & 13.83 & 8.09 \\
\hline
\end{tabular}

Source: Meek et al. (1995) and Chau and Gray (2002)

\section{HYPOTHESES DEVELOPMENT}

\section{Corporate Governance as Board of Directors Quality and Voluntary Disclosure}

The relationship between the quality of the BOD and the level of voluntary disclosure of companies had been examined in previous research. Based on previous studies, this study identified the quality of the BOD to comprise the following:

\section{Board's Leadership Structure}

A study by the SET (2003) has shown that $87 \%$ of Thai public listed companies separate the title of chairman of the board from that of the head of management teams. Nonetheless, only $21 \%$ of Thai public listed companies have independent chairmen. A possible reason could be that Thai public listed companies are initially family-owned and it is the majority shareholders that elect their chairmen.

The BOD leadership structure or the position of the chairperson of the board was found to be an important determinant in improving the effectiveness of the board's monitoring. Studies by Balachandran and Bliss (2004), Gul and Leung (2004), Huafang and Jianguo (2007), and Williams (2002) had found that CEO duality could negatively affect the level of voluntary disclosure. Furthermore, Van Der Zahn (2004) found that the role of CEO and board chairman separation is more likely to voluntary audit committee disclosure increases. This study would like to examine the relationship between the quality of board's leadership structure and the level of voluntary disclosure, and predict the direction of this relationship. Thus, this study hypothesised that:

$\mathbf{H}_{1(1)}$ : There is a positive relationship between the existence of board chairman-CEO separation and the level of voluntary disclosure.

$\mathbf{H}_{1(2)}$ : There is a positive relationship between the existence of chairman of the board being an independent non-executive director and the level of voluntary disclosure.

\section{Board's Composition}

A study by the SET (2003) found that $98 \%$ of public listed companies in Thailand have at least three independent directors. In-depth analysis revealed that $67 \%$ have three independent directors while $31 \%$ have 4 to 14 independent directors. Only $2 \%$ of the companies have less than three independent directors. The results also showed that only $4 \%$ of the companies have the proportion of having more than half of the board who are independent directors. The possible reasons are large board sizes, possible misunderstanding of the qualifications of an independent director, the difficulties involved in recruiting independent directors, and the cost 
involved especially in recruiting an independent director in small companies. In addition, there is no requirement in the Public Company's Act (PCA) of 1992 for Thai public listed companies to appoint independent non-executive directors. However, the SEC and the SET require listed companies to appoint at least two outside directors who are independent of the majority shareholders and management.

The objective of the requirement is to have directors who are able to provide an effective and unbiased oversight of the way in which the company is managed. Independent non-executive directors are supposed to safeguard the interests of the company, which includes minority shareholders, against any abuse by the management. They are required to give opinions on the related transactions and provide comments in the annual report (Nikomborirak, 2001). The board's composition is important as the primary role of the board is to control the management function of an organisation (Pound, 1995). A board comprising a number of independent non-executive directors (INDs) will enhance the behaviour of the management of an organisation (Rosenstein \& Wyatt, 1990). Additionally, a higher proportion of INDs on the board should result in more voluntary corporate disclosures (Fama \& Jensen, 1983a). The higher the proportion of INDs, the higher is the quality of the information disclosed (Forker, 1992). Willekens et al. (2004) found that the board's independence could positively affect the level of voluntary disclosure. This discussion leads the authors to hypothesise that if more than $50 \%$ of the directors on the board are INDs, they could positively affect the level of voluntary disclosure. This is supported by studies by Balachandran and Bliss (2004), Mohd-Nasir and Abdullah (2005), and Williams (2002). This study would like to examine the relationship between the quality of board's composition and the level of voluntary disclosure, and predict the direction of this relationship. Thus, this study hypothesised that:

$\mathbf{H}_{1(3)}$ : There is a positive relationship between the existence of more than half of the directors on the board being independent non-executive directors and the level of voluntary disclosure.

$\mathbf{H}_{1(4)}$ : There is a positive relationship between the existence of more than three directors of the board being independent non-executive directors and the level of voluntary disclosure.

\section{Board of Directors' Meetings}

The board of directors' meetings should be scheduled in advance. At these meetings, the chairman of the board should promote prudent consideration and allocate appropriate time for the management to present issues adequately and enough for the directors to broadly discuss important matters with care. It is the duty of the directors to attend every board meeting, except with reasonable excuses (SET, 2001a). A study by the SET (2003) found that on average, nine board meetings were held in 2002. About $11 \%$ of companies held four meetings a year. In terms of sectors, the boards of these five sectors meet most frequently; the sectors are: banking (13 times); jewelry and ornaments (12 times); energy, finance, and securities, and property development (11 times). This study showed that $45 \%$ of the listed companies disclose the total attendance of each director in their annual reports. Some companies choose to disclose the details expressed as a percentage rather than stating each director's actual attendance.

With regard to the frequency of board meetings, Vafeas (1999) found that the annual number of board meetings (more than 11 times) is inversely related to firm value. This suggests that board activity, measured by board meeting frequency, is an important dimension of board operations. Lipton and Lorsch (1992) found that the most widely shared problem that directors face is the lack of time to carry out their duties (Conger, Finegold \& Lawler, 1998) and that the amount of time spent in a board meeting is an important means to improve the effectiveness of a board. However, empirical studies on the frequency of board meetings have produced mixed results. Thus, attendance at board meetings is only one indicator of a director's contribution to the company and does not show whether a director actually contributes actively to board 
discussions (S\&P \& CGFRC, 2004). This study would like to examine the relationship between the quality of board's meetings and the level of voluntary disclosure, and predict the direction of this relationship. Thus, this study hypothesised that:

$\mathbf{H}_{1(5)}$ : There is a positive relationship between the existence of all directors on board that attend every board meetings per year and the level of voluntary disclosure.

$\mathbf{H}_{\mathbf{1 ( 6 )}}$ : There is a positive relationship between the existence of board's meetings of more than four meetings a year and the level of voluntary disclosure.

Board's Controlling System and Internal Audit The BOD should provide, maintain, and review a controlling system in which financial, operations, and compliance controls are incorporated. The system should also comprise risk management and pay a great deal of attention to all the early warning signs and extraordinary items. The board should commence internal audit activities by setting up a separate unit within the company to handle them. A study by the SET (2003) has shown that on average, $67 \%$ of Thai public listed companies' report that their internal control is in place. The study also found that $75 \%$ of the listed companies establish their own internal audit units, $8 \%$ employed outsiders, $2 \%$ have their parent companies perform the function, and the remaining $15 \%$ do not disclose any information at all about their internal audit function. $75 \%$ of the internal audit functions report solely to the audit committee while only $35 \%$ report to the audit committee and the managing director or the board.

With regard to the board's controlling system and internal audit, Rezaee (2003) found that the internal audit function is the first line of defense against fraud. Internal audit now focuses on a broad range of activities and is becoming an integral part of corporate governance. Willekens et al. (2004) found that the internal audit department could positively affect the level of voluntary disclosure. This study would like to examine the relationship between the quality of board's controlling system and internal audit and the level of voluntary disclosure, and predict the direction of this relationship. Thus, this study hypothesised that:

$\mathbf{H}_{1(7)}$ : There is a positive relationship between the existence of internal audit department being in company and the level of voluntary disclosure.

\section{Audit Committee's (AC's) Leadership Structure}

The board should provide for committees, especially for audit committees, to help the board in studying various issues in detail and screening workload according to certain situations. It should be clearly provided in the policy and the framework regarding qualities of members in the committees, their job responsibilities, conduct of meetings, and reporting to the board. All or most members of the committees should be non-executive directors while chairmen of the committees should be independent non-executive directors (SET, 2001a).

With regard to the audit committee's leadership structure, Spangler and Braiotta (1990) found a positive association between the AC's effectiveness and transformational leadership, and some transactional leadership characteristics (contingent rewards and active management being the exception). Haniffa and Cooke (2002) found that the position of the chairperson is thought to be important in improving the board's effectiveness. Studies by Berg and Smith (1978), Donaldson and Davis (1991), and Rechner and Dalton (1991) found that independent nonexecutive chairpersons assist in improving the company's performance. They predicted that there is a positive association between a nonexecutive chairperson and the extent of voluntary disclosure of information. In contrast, they found that the chairperson as a non-executive director is negatively associated with the extent of voluntary disclosure and has the highest regression coefficient. The findings suggested that a nonexecutive chairperson, as an agent, obtains greater utility by keeping private information secret. However, Liu (2004) provided evidence that audit committees comprising of independent nonexecutive directors enhance disclosure quality. This study would like to examine the relationship 
between the quality of AC's leadership structure and the level of voluntary disclosure, and predict the direction of this relationship. Thus, this study hypothesised that:

$\mathbf{H}_{1(8)}$ : There is a positive relationship between the existence of audit committee's chairman being an independent non-executive director and the level of voluntary disclosure.

\section{AC's Composition}

The SET (1999) best practice guidelines for audit committees stipulated that AC members should have at least three INDs and the number of AC members should be between three to five people; all or most members of the committees should be non-executive directors. As cited in a study by SET (2001a), it was found that at least one member of the audit committee is an employee of the firm, its subsidiary, or associated firm, representing major/controlling shareholders, a relative of the management, other blockholders, business group, bank affiliated, former employee, and other business relationship.

With respect to the audit committee's composition, Klein (2002) suggested that the independence of the AC may be affected by the independence of the board in general. Pincus, Rusbarsky and Wong, (1989) found a positive association between the establishment of ACs and the percentage of outside directors on the board. Balachandran and Bliss (2004), Ho and Wong (2001), and Liu (2004) found that members of the AC who are INDs could positively affect the level of voluntary disclosure. This study would like to examine the relationship between the quality of AC's composition and the level of voluntary disclosure, and predict the direction of this relationship. Thus, this study hypothesised that:

$\mathbf{H}_{1(9)}$ : There is a positive relationship between the existence of at least three AC members being independent non-executive directors on the audit committee and the level of voluntary disclosure.

$\mathbf{H}_{\mathbf{1 ( 1 0 )}}$ : There is a positive relationship between the existence of all members of AC being independent non- executive directors on the audit committee and the level of voluntary disclosure.

\section{AC's Meetings}

The audit committee should hold meetings to consider matters such as compliance of the financial statement with the accounting standards and also if there is a change in accounting policies made by the company. These matters should be considered before submission to the BOD for disclosure to the shareholders and general investors. The frequency of the meetings in each year will depend on the size of the business and the duties delegated so as to ensure that the work performance of the audit committee meets the objectives which have been intended for. The Best Practice Guideline for audit committees of the SET (1999) stated that the audit committee meetings should be held on an average of four times a year. It was found that $35 \%$ of Thai listed companies have more than four audit committee meetings in 2002 while $30 \%$ have four audit committee meetings. Most of the audit committees that met less than four times per year were the newly listed companies (SET, 2003).

McMullen and Raghunandan (1996) found that companies with reporting problems had less frequent audit committee meetings. Scarbrough, Rama \& Raghunandan, (1998) surveyed chief internal auditors (CIA) and found a positive association between the AC's independence and the frequencies of meetings with internal auditors (IAs) as well as a review of the IA's work. Abbott and Parker (2000) studied auditor selection for 500 companies and found that firms with audit committees that meet at least twice per year were more likely to use specialist auditors. Nevertheless, Liu (2004) found that the AC's meeting frequency positively affect the level of voluntary disclosure. This study would like to examine the relationship between the quality of AC's meetings and the level of voluntary disclosure, and predict the direction of this relationship. Thus, this study hypothesised that:

$\mathbf{H}_{\mathbf{1 ( 1 )}}$ : There is a positive relationship between the existence of all AC members that attend every AC meetings per year and the level of voluntary disclosure.

$\mathbf{H}_{1(12)}$ : There is a positive relationship between the existence of AC's meetings of more than four meetings a year and the level of voluntary disclosure. 
AC's Knowledge and Expertise

Since one of the roles of audit committees is to review the financial statements, the educational background of the members of the audit committee is important. The SET requires that at least one member of the audit committee must have an accounting or finance background. The results of a study by the SET (2003) indicated that $80 \%$ of Thai public listed companies have at least one member of the audit committee with an accounting or a finance background, either educational or work experience. Only 9\% have all members of the committee with these qualifications. In terms of accounting or finance education, $58 \%$ of the companies have at least one member of the audit committee with a bachelor degree in either field. The remaining $20 \%$ can be divided into three groups: $5 \%$ do not have any member of the audit committee with the relevant background, $14 \%$ are unable to identify the background, and $1 \%$ not have an audit committee at all.

The AC's knowledge and expertise will improve its effectiveness as they would be able to probe management with the right questions and assist auditors in their investigations (Levitt, 2000). Felo, Krisnamurthy and Solieri, (2003) found that the quality of financial reporting is positively related to the existence of financial expertise in the audit committee. Mangena and Pike (2005) found that there exists a significant positive association between the quality of interim financial reporting and the presence of financial expertise in the AC. This study would like to examine the relationship between the quality of AC's knowledge and expertise in the level of voluntary disclosure, and predict the direction of this relationship. Thus, this study hypothesised that:

$\mathbf{H}_{1(13)}$ : There is a positive relationship between the existence of all AC members that have financial literacy and the level of voluntary disclosure.

$\mathbf{H}_{1(14)}$ : There is a positive relationship between the existence of at least one AC member being a financial reporting expert such as CPA and the level of voluntary disclosure.

\section{Remuneration Committee ( $R C$ )'s Leadership Structure}

The board should form a remuneration committee to assist it in studying various issues in detail and screening workload according to certain situations. It should be clearly provided in the policy and the framework regarding the qualities of members in the committees, their job responsibilities, conduct of meetings, and reporting to the board. All or most members of the committees should be non-executive directors while the chairmen of the committees should be independent non-executive directors (SET, 2001a). A study by SET (2003) found that only $19 \%$ of Thai public listed companies established remuneration committees. Of those that do not have remuneration committees, $28 \%$ stated their reasons for not forming one. Some of the companies stated that the size of their company is too small. Others stated that they already have an appropriate procedure for determining the remuneration package, that involves the whole board when setting the directors' remuneration. The study by SET (2003) also found that $10 \%$ of the listed companies that have remuneration committees have a non-executive director as their chairman.

As cited in Haniffa and Cooke (2002), the position of the chairperson is also thought to be important in improving the effectiveness of the board. Studies by Berg and Smith (1978), Donaldson and Davis (1991), and Rechner and Dalton (1991) found that independent nonexecutive chairpersons do help to improve the company's performance. They predicted that there is a positive association between a nonexecutive chairperson and the extent of voluntary disclosure of information. This study would like to examine the relationship between the quality of remuneration committee's leadership structure and the level of voluntary disclosure, and predict the direction of this relationship. Thus, this study hypothesised that:

$\mathbf{H}_{1(15)}$ : There is a positive relationship between the existence of remuneration committee's chairman being an independent nonexecutive director and the level of voluntary disclosure. 


\section{$R C$ 's Composition}

A study by SET (2003) found that $14 \%$ of the listed companies in Thailand that have a remuneration committee, have non-executive directors as the majority of the remuneration committee members. A remuneration committee is not required by law or by SEC regulations. The remuneration of directors requires a vote of $75 \%$ of the shareholders. Since many listed companies are still family run, small shareholders often own less than $10 \%$ equity share and thus are not able to regulate the compensation of directors. In such companies, large shareholders are thus able to provide excessive compensation to friends and families or nominee directors. However, several companies that have a significant foreign holding are voluntarily introducing remuneration committees for greater transparency and efficiency in the management of their personnel (Nikomborirak, 2001).

The RC is one of the most important recommendations of the Cadbury Committee (Cadbury Report, 1992). The RC would be able to assist in enhancing accountability through appropriate information disclosure, and hence, instill greater confidence in the company's corporate governance system. Remuneration committees were recommended to include only non-executive directors as there is a clear conflict of interest when executive directors participate in their own compensation decisions (Diacon \& O’Sullivan, 1996).

Vafeas and Afxentiou (1998) examined changes in the composition of remuneration committees following the adoption of the SEC compensation disclosure rule 33-6962 (US SEC, 1992; Vafeas \& Theodorou, 1998). They found that firms remove a significant number of corporate executives from remuneration committees following the rule and replace them with non-executives holding a relatively high number of outside directorships. One possible interpretation for this result was that in fear of market pressure, firms restructure their monitoring committees to be more independent, in accordance with the interest of their shareholders. This study would like to examine the relationship between the quality of RC's composition and the level of voluntary disclosure, and predict the direction of this relationship. Thus, this study hypothesised that:

$\mathbf{H}_{\mathbf{1 ( 1 6 )}}$ : There is a positive relationship between the existence of more than half of the RC members being non-executive directors and the level of voluntary disclosure.

\section{Board of Directors' Quality Index}

Willekens et al. (2004) created a corporate governance index which measures the overall the strength of a company's corporate governance system and predicted that board independence, the existence of an audit committee, higher audit quality as well as the existence of an internal audit department can enhance corporate reporting. Willekens et al. (2004) suggested that higher scores indicate stronger corporate governance systems and predict a positive coefficient on level of corporate governance. This study would like to examine the relationship between the board of directors' quality index which is associated with the quality of the board's leadership structure, composition, meetings, controlling system, committees, the audit committee and the remuneration committee and the level of voluntary disclosure, and predict the direction of this relationship. Thus, this study hypothesised that:

$\mathbf{H}_{\mathbf{1 ( 1 7 )}}$ : There is a positive relationship between the level of board of directors' quality and the level of voluntary disclosure.

\section{Moderator Effect of Executive Directors on the Relationship between Corporate Governance and Voluntary Disclosure}

This study intended to examine the effect of managerial ownership on the relationship of board's quality to voluntary disclosure. Managerial ownership is measured by the percentage of shares held by executive directors and includes his/her family as a single unit (McClelland \& Barker, 2004).

The study by Jensen and Meckling (1976) found that when managerial ownership is low, there is a greater agency problem, that is, the manager has greater incentives to consume perks and reduce incentives to maximise job performance. Thus, outside shareholders will 
increase monitoring of the manager's behaviour to reduce the agency problem. Beatty and Zajac (1994) found that companies with a lower level of board's ownership are associated with a higher level of firm monitoring. Higher level of monitoring is represented by a larger percentage of outside directors or separate CEO and board chairman positions. Hence, an increase in board ownership prefer to result in less monitoring, i.e. a lower proportion of outside directors and a more unitary leadership structure.

The study by Bathala and Rao (1995) found a negative significant relationship between board ownership and the proportion of outside directors on the board. A study by Whidbee (1997), as cited in SET (2001b), argued that the relationship between determinants of the board composition in the US reflects the ownership structure of the firm. In particular, he found that managers with high equity stakes use their voting rights to exclude outside directors from the board membership. Thus, an increase in outside directors reduces voluntary disclosure. This is consistent with a substitute relationship between outside directors and disclosure in monitoring managerial ownership (Eng \& Mak, 2003).

The study by Wiwattanakantang (2000) found that Thai listed companies' ownership structure is highly concentrated and most of the shares are owned by executive directors as a result, managers and owners are the same person. Chen and Jaggi (2000) found that the appointment of independent non-executive directors in companies which managers with high equity stakes is likely to be influenced by the management's close relationship with perspective independent non-executive directors and the likelihood of their support for the management's conception and policies. Consequently, in the presence of managerial ownership and control independent non-executive directors' independence may be compromised and their contribution to improve the management's responsiveness to investors might be reduced. Hence, these factors may reduce the independent non-executive directors' effectiveness in managerial ownership and controlled firms which managers with high equity stakes (Nielsen, Peck \& Ruigrok, 2008). Mak and Li (2001) found that the proportion of outside directors is negatively significanty related. Gompers, Ishii and Metrick, (2003) as cited in Brown and Caylor (2006) argued that there are countervailing incentives for managers to reduce the quality of accounting information. Consequently, the voting rights included in equity ownership make managers less subject to career concerns, the discipline of the product market, monitoring by outside shareholders, and valueenhancing takeovers.

Jensen and Meckling (1976) argued that the agency theory suggested that as managers own less of the firm, the demand for accountingbased performance measures to monitor manager increases. However, Warfield, Wild and Wild, (1995) argued that managers may impair the faithful determination of accounting numbers in order to meet the performance measures which are imposed by the accounting based contracts. Therefore, the quality of financial reporting may be positively associated with managerial equity ownership since it helps align the interests of the managers and the shareholders. In contrast, Gompers et al. (2003) as cited in Brown and Caylor (2006) found that there are countervailing incentives for managers to reduce the quality of accounting information. The voting rights included in equity ownership make managers less subject to career concerns, the discipline of the product market, monitoring by outside shareholders, and value-enhancing takeovers. Thus, managers will reduce the reporting quality if there exist the proprietary costs of disclosure, since the less managers disclose, the less competitors and suppliers know about the company's financial position (Darrough \& Stoughton, 1990; Dye, 1985, 1986; Hayes \& Lundholm, 1996; Luo, 2006; Verrecchia, 1983, 1990; Wagenhofer, 1990; Han, 2005). This study would like to examine the role of types of executive directors and concentration of executive directors' ownership on the relationship of the board of directors' quality to the level of voluntary disclosure, and predict the direction of this relationship. Thus, this study hypothesised that: 
$\mathbf{H}_{21}$ : An executive director that has the family member, largest shareholder involved will negatively moderate the relationship between each dimension of board of directors' quality and the level of voluntary disclosure.

$\mathbf{H}_{2.2}$ : A high concentration of executive directors' ownership will negatively moderate the relationship between each dimension of board of directors' quality and the level of voluntary disclosure.

\section{RESEARCH DESIGN}

This section on research design helps explain where this study obtained the data, how this study operationalised the dependent, independent, moderating, and control variables, and the form of analysis being undertaken to test the hypotheses.

\section{Population and Sample}

All 441 companies listed in the Stock Exchange of Thailand (SET) in 2004 were used as the population in this study. 2004 was chosen as this is the most recent data available. This study used all non-financial listed companies listed in the Stock Exchange of Thailand (SET), totaling 378 companies. However, only data from 317 was obtained for the study, and 61 companies were not included. Reasons for non-inclusion are explained in Table 3.

Table 3: Sample Criteria

\begin{tabular}{lcc}
\hline \multicolumn{1}{c}{ Description } & $\begin{array}{c}\text { No. of listed } \\
\text { Companies }\end{array}$ & $\begin{array}{c}\text { Percentage of total } \\
\text { population }\end{array}$ \\
\hline $\begin{array}{l}\text { Population } \\
\text { All companies listed in the SET as of 31 December 2004 }\end{array}$ & 441 & 100.00 \\
$\begin{array}{l}\text { Deduct } \\
\text { Listed companies in Financial Sector for the year 2004 }\end{array}$ & $\underline{(14.3)}$ \\
$\begin{array}{l}\text { Listed companies that are the sample for the year 2004 } \\
\text { Deduct }\end{array}$ & 378 & 85.7 \\
$\begin{array}{l}\text { Data needed for the study not available (example data such audit committee and/ } \\
\text { or board of directors, and/or ownership or control variables not available) } \\
\text { New listed companies- data not available }\end{array}$ & $(54)$ & $\underline{(7)}$ \\
$\begin{array}{l}\text { Final Sample } \\
\text { Listed companies with usable data that are final sample for the year 2004 }\end{array}$ & $\underline{\underline{317}}$ & $\underline{(1.6)}$ \\
\hline
\end{tabular}

The 317 companies used in this study are from seven sectors; Sector 1 is Agriculture \& Food Industry: 42 companies or 13.2\%; Sector 2 is Consumer Products: 35 companies or 11.0\%; Sector 4 is Industrial: 45 companies or 14.2\%; Sector 5 is Property \& Construction: 64 companies or 20.2\%; Sector 6 is Resources: 16 companies or 5.1\%; Sector 7 is Services: 75 companies or 23.7\%; and Sector 8 is Technology: 40 companies or $12.6 \%$.

\begin{tabular}{lcc}
\hline \multicolumn{1}{c}{ Sector } & No. of companies & Percentage \\
\hline Agriculture \& Food Industry Sector & 42 & $13.2 \%$ \\
Consumer Products Sector & 35 & $11.0 \%$ \\
Industrials Sector & 45 & $14.2 \%$ \\
Property \& Construction Sector & 64 & $20.2 \%$ \\
Resources Sector & 16 & $5.1 \%$ \\
Services Sector & 75 & $23.7 \%$ \\
Technology Sector & 40 & $12.6 \%$ \\
\hline \multicolumn{1}{c}{ Total } & 317 & $100.0 \%$ \\
\hline
\end{tabular}

Figure 1: The 317 companies used in this study 


\section{DEPENDENT VARIABLE}

\section{Voluntary Disclosure Checklist}

Leventis and Weetman (2000) argued that the theoretical and empirical literature has no principle certainty in the treatment of voluntary disclosures. In contrast, Meek et al. (1995) suggested the separation of voluntary disclosures into categories according to their specific nature. The voluntary disclosure checklist of this study was adopted from both Meek et al. (1995) and Chau and Gray (2002). The checklist by Chau and Gray (2002) was based on an analysis of two important Asian markets, namely, Hong Kong and Singapore. It also provided a useful benchmark for comparison with earlier research. Meek et al. (1995) and Chau and Gray (2002) categorised the voluntary disclosure information into three types: (1) strategic, (2) non-financial, and (3) financial.

The study initially combined both the checklists by Meek et al. (1995) and Chau and Gray (2002). Whenever an item appeared in either study, it was included in the study's checklist. Upon completion of this, the study ended up with a total of 115 items in its voluntary disclosure checklist. After this stage, the study then eliminated the items that were mandated by SET. The mandatory items were determined through interviews with the regulators and also by examining the regulatory requirements of Thailand, namely, the Accounting Act (2000), the Stock Exchange of Thailand (SET), the Stock Exchange Commission of Thailand (SEC), and the Public Companies Act (1992). This resulted in a voluntary disclosure checklist comprising 70 items. To validate that the checklist did include only voluntary disclosure items, it was subjected to evaluation by a few Certified Public Accountants in Thailand. They confirmed that the 70 -item checklist can be used for the purpose of the study (see Appendix 1).

\section{Categories of Voluntary Disclosure}

Strategic information includes general corporate information, corporate strategy, research and development, and future prospects. Non-financial information includes employee information, social policy and value added information. Financial information includes segmental information, financial review, foreign currency information, and stock price information. Strategic and financial types of information have decision relevance to investors while non-financial information is directed toward a corporation's social accountability and targeted at a wider spectrum of stakeholders other than owners/ investors (Chau \& Gray, 2002).

Some items in the employee information, for example, amount spent in training, nature of training, policy on training, categories of employees trained, and number of employees trained, are directed toward the principles of good corporate governance of the SET (2001a) No. 15. This guideline suggested that the board of directors should ensure that the company discloses important information correctly, timely, and transparently. It is also recommended that the board provide an Investor Relations Unit to represent the company when communicating with institutional and individual investors, stock analysts in general, and state agencies concerned. Other recommendations also included that the board should provide for adequate resources to help develop the knowledge and the ability of company personnel in their communication and presentation of information.

The 70-item voluntary disclosure checklist comprised 16 items of strategic information, 27 items of non-financial information, and 27 items of financial information. Most of the prior studies and this present study related to corporate information disclosure had tended to treat voluntary disclosure as overall information (Chau \& Gray, 2002).

\section{Scoring the Voluntary Disclosure Items and Disclosure Index}

The Voluntary Disclosure Index was based on the 70 disclosure items. Scoring and disclosure indexes of the voluntary disclosure items under the unweighted voluntary disclosure index were adopted from Cooke (1989a). The additive model used in this study was unweighted. The implied assumption is that each item of disclosure is equally important. This study used a dichotomous procedure in which an item scores one if it is disclosed and zero if it is not disclosed. The total score of voluntary disclosure $\left(\mathrm{V}_{j}\right)$ for a company $j$ is additive: 
70

$\mathrm{V}_{j}=\sum_{i=1} \mathrm{~d}_{i j}$

where, $j=1$ to $317, i=1$ to 70 ;

$\mathrm{d}_{i j}=1$ if the voluntary disclosure item $d_{i}$ is disclosed and

0 if the voluntary disclosure item $d_{i}$ is not disclosed for company $j$.

Once all items have been scored an index is created to measure the relative level of disclosure by a company. The index is a ratio of the actual scores awarded to a company to the scores which that company is expected to earn. Consequently, a company is not penalised for those items that are not relevant to it. Thus, the maximum score $\left(\mathrm{M}_{j}\right)$ companies can earn varies:

$$
\mathrm{M}_{j}=\sum_{\mathrm{i}=1}^{n_{j}} \mathrm{~d}_{i j}
$$

where $d_{i j}=$ the maximum possible number of voluntary disclosure items items expected to be disclosed by a company $j$;

$n_{j} \quad=\quad$ the number of items which a company $j$ is expected to disclose, i.e. $\mathrm{n} \leq 70$ for a company $j$ (discussed below).

Where there is no mention in the corporate annual report of a disclosure item, for example, foreign currency information, it is concluded that the item

Table 4: Measurement of Independent Variables of disclosure was not relevant to that company. Consequently, a company is not penalised for nondisclosure of information that was not relevant to it. In contrast, if it is apparent that an item of disclosure is relevant, for example, by mentioning transactions about import and/or export but without disclosing foreign currency information, then clearly $d_{i}=0$.

The relative voluntary disclosure index (VDI ) for each company $j$ is measured by an index which is the proportion of the total score of voluntary disclosure $\left(\mathrm{V}_{j}\right)$ awarded to a company $j$ to the score which that company $j$ could at most be expected to disclose as the maximum score $\left(\mathrm{M}_{j}\right)$. Thus, the voluntary disclosure index score can range from zero (i.e. $0 \%)$ to one (i.e. $100 \%)$; $(0$ $\left.\leq \mathrm{VDI}_{j} \leq 1\right)$ to be used in the statistical analyses.

\section{INDEPENDENT VARIABLES}

\section{Quality of Board of Directors Index}

A total of 10 dimensions and 16 items of the board of directors' quality were used to measure the board of directors' quality index (BOQI). This study assigns a score of " 1 " if the item is present and " 0 " if the item is absent. The study assumes that the higher the score of the BOQI, the higher is the quality of BOD. The measurement for each dimension is shown in Table 4.
Quality of Board of Directors

1. Quality of Board's Leadership Structure

The titles and authority of the board's chairman and head of management team are clearly separated

The chairman of the board is an independent nonexecutive director (IND)

2. Quality of Board's Composition

More than half of the directors on the board are INDs

More than three directors of the board are INDs
Measurement of BOQI, code and principle, and prior studies are used

Comply with No.9 of the Principles of Good Corporate Governance (SET, 2001a) score 1

(Evans, 2004)

Comply with No.8 of the Principles of Good Corporate Governance (SET, 2001a) score 1 ( Karamanou \& Vafeas, 2005; Vafeas, 1999; Willekens et al., 2004) 
(continued)

3. Quality of Board's Meetings

All directors on board to attend every board meetings

Board's meetings more than 4 meetings a year

4. Quality of Board's Controlling System and Internal Audit

The existence of internal audit department is in company

5. Quality of AC's Leadership Structure

The chairman of AC is an IND

6. Quality of AC's Composition

At least three AC members are INDs

All members of AC are INDs

\section{Quality of AC's Meetings}

All AC members are to attend every AC meetings

AC's meetings more than 4 meetings a year

8. Quality of AC's Knowledge and Expertise

All AC members have financial literacy

At least one AC member is a financial

$$
\text { reporting expert as } \mathrm{CPA}
$$

9. Quality of RC's Leadership Structure

The chairman of RC is an IND

10. Quality of RC's Composition

More than half of the RC members are non-executive directors
Comply with No.11 of the Principles of Good Corporate Governance (SET, 2001a) score 1 (Evans, 2004; Karamanou \& Vafeas, 2005; Vafeas, 1999)

Comply with No.13 of the Principles of Good Corporate (SET, 2001a) Governance score 1 (Willekens et al., 2004)

Comply with No.12 of the Principles of Good Corporate Governance (SET, 2001a) score 1 (Haniffa \& Cooke, 2002)

Comply with No. 3.1 of Best Practice Guidelines for Audit Committee (SET, 1999) score 1

(Ho \& Wong, 2001; Karamanou \& Vafeas, 2005; Willekens et al., 2004)

Comply with No.11 of the Principles of Good Corporate Governance (SET, 2001a) score 1 (Evans, 2004; Karamanou \& Vafeas, 2005; Liu, 2004)

Comply with No. 3.3 of Best Practice Guidelines for Audit Committee (SET, 1999) score 1

(Karamanou \& Vafeas, 2005; Mangena \& Pike, 2005)

Comply with No.12 of the Principles of Good Corporate Governance (SET, 2001a) score 1

(Haniffa \& Cooke, 2002)

Comply with No.12 of the Principles of Good Corporate Governance (SET, 2001a) score 1 (Vafeas \& Theodorou, 1998) 


\section{MODERATING VARIABLES}

\section{Type of Executive Director}

The variables of types of executive director are presented as an executive director that has the family member and largest shareholder involved as adapted from Yammeesri and Lodh (2002). The dummy variable is set to be one for firms with type of executive director that has the family member, and largest shareholder involved (TEXF), and zero for firms with type of executive director that has no the family member, and largest shareholder involved.

Concentration of Executive Directors' Ownership Executive directors controlling ownership is defined as the percentage of shares held by executive directors which includes ownership by his/her family member. A high concentration of executive directors' ownership (HLEX) is defined as executive directors' ownership that is higher than the median and a low concentration of executive directors' ownership is defined as executive directors' ownership that is lower than or equal to the median (adapted from McClelland \& Barker, 2004).

\section{Types of Moderating Effect}

Types of moderator variables (Sharma, Durand \& Gur-Arie, 1981) such as Type 1, the specification variable is related to the criterion and/or predictor variable but does not interact with the predictor (Quadrant 1), that is, not a moderator variable but simply an independent predictor variable. Type 2, the type of moderator in Quadrant 2, influences the strength of the relationship, does not interact with the predictor variable, and is not significantly related to either the predictor or criterion variable. Type 3 , the moderator variable in Quadrant 3, is identical to that the former, but not only interacts with the predictor variable but is a predictor variable itself. Type 4, this type of moderator variable fits in Quadrant 4 and conforms to the psychometric definition of a pure moderator variable. That is, psychometrically, a moderator variable should enter into interaction with predictor variables, while having a negligible correlation with the criterion itself (Cohen \& Cohen, 1975).

\section{Control Variables}

Control variables comprise firm characteristics which can be categorised into: (1) firm-specific characteristics related to performance (i.e. profitability which is measured by profit margin and earnings return, and liquidity ratios), (2) structure (i.e. debt-equity ratios, firm size measured by total assets, total sales and market capitalisation), and (3) market (i.e. scope of business operations and auditor size influence), which were adapted from Chen and Jaggi (2000).

Table 5: Summary of the Operationalisation of Control Variables

\begin{tabular}{|c|c|c|c|}
\hline Construct & Operationalisation & $\begin{array}{l}\text { Expected } \\
\text { Sign }\end{array}$ & $\begin{array}{c}\text { Prior Studies used as control } \\
\text { variables }\end{array}$ \\
\hline \multicolumn{4}{|c|}{$\begin{array}{l}\text { a. Characteristics related to } \\
\text { performance }\end{array}$} \\
\hline PPM & $\begin{array}{l}\text { Profit margin }=\text { income before extraordinary } \\
\text { items }(\text { IBEX) to net sales }\end{array}$ & + & Chen \& Jaggi (2000) \\
\hline ROE & $\begin{array}{l}\text { Earnings return }=\text { IBEX to book value of } \\
\text { equity for the beginning of the period }\end{array}$ & + & $\begin{array}{c}\text { Balachandran \& Bliss (2004) } \\
\text { Chen \& Jaggi (2000) } \\
\text { Eng \& Mak (2003) } \\
\text { Gul \& Leung (2004) } \\
\text { Ho \& Wong (2001) }\end{array}$ \\
\hline $\mathrm{CR}$ & $\begin{array}{l}\text { Liquidity ratio = current assets to current } \\
\text { liabilities }\end{array}$ & + & $\begin{array}{c}\text { Balachandran \& Bliss (2004), } \\
\text { Chen \& Jaggi (2000) } \\
\text { Gul \& Leung (2004) }\end{array}$ \\
\hline
\end{tabular}


(continued)

b. Characteristics related to structure

DE

Debt-equity ratio $=$ long-term liability to book value of common stocks

Firm size $=$ natural logarithm of total assets

Firm size $=$ natural logarithm of net sales

Firm size $=$ natural logarithm of market capitalisation
Balachandran \& Bliss (2004)

Chen \& Jaggi (2000)

Eng \& Mak (2003)

Gul \& Leung (2004)

Ho \& Wong (2001)

Willekens et al. (2004)

Chen \& Jaggi (2000),

Gul \& Leung (2004),

Ho \& Wong (2001),

Karamanou \& Vafeas (2005),

Willekens et al. (2004)

Chen \& Jaggi (2000)

Evans (2004)

Balachandran \& Bliss (2004)

Chen \& Jaggi (2000)

Eng \& Mak (2003)

c. Characteristics related to market

Scope of business operations = dummy; $=$ 1 if company is a conglomerate firm; $=0$ if company is a non-conglomerate firm

Type of audit firm = dummy; $=1$ if type of audit firm is Big4; $=0$ if type of audit firm is non-Big4
$+$

Chen \& Jaggi (2000)

Balachandran \& Bliss (2004),

Chen \& Jaggi (2000)

Eng \& Mak (2003)

Gul \& Leung (2004)
- The relationships as to the extent or quality of disclosure in corporate annual reports (dependent variable), firm characteristics (control variables), and corporate governance characteristics (independent variables) had been examined in several countries. These firm-specific characteristics as control variables were used by Balachandran and Bliss (2004), Chen and Jaggi (2000), Eng and Mak (2003), Evans (2004), Gul and Leung (2004), Ho and Wong (2001), Karamanou and Vafeas (2005), and Willekens et al. (2004), such as debt-equity ratio which is defined as the ratio of long-term debt over book value of common equity, firm size is measured by total assets, liquidity ratio is defined as the ratio of current assets over current liabilities; earnings return is defined as the ratio of income before extraordinary items (IBEX) over book value of equity for the beginning of the period; profit margin is defined as IBEX over net sales, scope of business operations is defined as conglomerate or non-conglomerate firms (see Table 6 as cited in Wiwattanakantang, 2000), audit firm size influence is defined as the Big4 international independent audit firms namely, PriceWaterhouseCoopers, Ernst \& Young, Deloitte and Touche, and KPMG. Thus, these variables were included in regression models as control variables.

Table 6: List of Thai Conglomerates

\begin{tabular}{cc}
\hline Group & Type of business \\
\hline Bangkok Bank Group & $\begin{array}{r}\text { Banking, finance, insurance, trading, textile, property development, agribusiness, } \\
\text { food, health care services } \\
\text { Banking, finance, insurance, trading, textile, property development, agribusiness, } \\
\text { food, health care services }\end{array}$ \\
\hline
\end{tabular}


(continued)

\begin{tabular}{|c|c|}
\hline $\begin{array}{l}\text { Bank of Ayudhaya } \\
\text { group }\end{array}$ & $\begin{array}{l}\text { Banking, insurance, flour milling, shipping, property development, agribusiness, } \\
\text { construction materials, silo and warehouses }\end{array}$ \\
\hline $\mathrm{CP}$ group & Agribusiness, agriculture, telecommunication, wholesale \\
\hline Central group & Hotel, property development, trading, department store \\
\hline Saha Union group & $\begin{array}{l}\text { Textile, trading, finance, cosmetics, computer, electrical appliance, plastic, agriculture, } \\
\text { footwear }\end{array}$ \\
\hline $\begin{array}{l}\text { Saha Pathanapibul } \\
\text { group }\end{array}$ & $\begin{array}{l}\text { Trading, textile, food products, consumer products, cosmetic products, property } \\
\text { development }\end{array}$ \\
\hline Siam Cement group & $\begin{array}{l}\text { Banking, finance, insurance, cement, steel, property development, pulp and paper, } \\
\text { glass, hotel }\end{array}$ \\
\hline $\begin{array}{l}\text { Sri Krung Wattana } \\
\text { group }\end{array}$ & Agribusiness, agriculture, trading, food products, steel, chemical, shipping \\
\hline Sun Hua Seng & Trading, agribusiness, agriculture, pulp and paper, shipping \\
\hline
\end{tabular}

\section{Source of Information}

Information on variables used in this study was based on a variety of sources. One set of data collection was used, i.e. secondary data. The secondary data was compiled through annual reports (Form 56-2) and report on the disclosure of additional information (Form 56-1) for the year of 2004, Fact Book of SET (2005), and listed company information from www.setsmart.com of the Stock Exchange of Thailand (SET). Secondary data were divided into four components, namely voluntary disclosure checklist, board of director characteristics quality index, firm characteristics, and types of the largest shareholder controlled firm, types of family member controlled firm, and ownership concentration of executive directors.

\section{DATA ANALYSIS}

Unit of analysis of this study is a cross-sectional survey research by data collection from secondary data.

Statistics Tool Before Using Hierarchical Regression Analysis

\section{Multicollinearity Testing from Pearson Correlation}

The correlation analysis was conducted on all of the study variables to check the presence of multicollinearity (if any), and to test the relationships between the variables. Multicollinearity between variables becomes a problem when the correlation between the variables exceeds .80 or .90 (Field, 2000; Mangena \& Pike, 2005). The results of the correlation analysis of variables are summarised in Table 8.

\section{Hierarchical Regression Equation}

The results of the four-step hierarchical regression are undertaken for hypotheses testing of control variables, independent variables, and moderating variables of this study, when the firm characteristics as control variables were entered into the regression equation in the first step; in step 2, by adding the independent variables, in the third step of moderating variables were entered into the equation in order to gauge its impact as an independent predictor, and in the fourth and final step, the interaction terms were entered into the Model, as follows: 


$$
\begin{aligned}
\text { VDI }_{j}=\beta_{0} & +\beta_{1} \text { BODS }_{\mathrm{ij}} & & +\beta_{2} \mathrm{MV}_{\mathrm{ij}} \\
& +\beta_{4} \mathrm{PPM}_{\mathrm{j}} & & +\beta_{5} \mathrm{ROE}_{\mathrm{j}} \\
& +\beta_{7} \mathrm{DE}_{\mathrm{j}} & & +\beta_{8} \text { LNTA }_{\mathrm{j}} \\
& +\beta_{10} \mathrm{BIG}_{\mathrm{j}} & & +\varepsilon_{\mathrm{j}}
\end{aligned}
$$$$
+\beta_{3} \mathrm{MV}_{\mathrm{ij}-} \mathrm{BODS}_{\mathrm{ij}}
$$$$
+\beta_{6} \mathrm{CR}_{\mathrm{j}}
$$$$
+\beta_{9} \mathrm{CONG}_{\mathrm{j}}
$$

Where: $\quad \mathrm{j}=$ Firm indicator $(1-317)$;

Dependent Variables Independent Variables

$\mathrm{VDI}_{\mathrm{j}}=$ Voluntary Disclosure Index of overall information, $0 \leq \mathrm{VDI}_{\mathrm{j}} \leq 1$ for company $\mathrm{j}$; $=$ Independent variables $(\mathrm{i}=1,2, \ldots$ 17); BODS1=BCEO, BODS2=BCIN, BODS3=BI51, BODS BODS4=BIAL, BODS5=BMAL, BODS6=BMA4, BODS7=BIAD, BODS8=ACCI, BODS9=IDAC, BODS10=ACIN, BODS11=ACMA, BODS12=ACA4, BODS13=ACFL, BODS14=ACEX, BODS15=RCCI, BODS16=RCPR, and BODS17= BOQI for company $\mathrm{j}$;

$\mathrm{BCEO}=$ The titles and authority of the board's chairman and head of management team are clearly separated (yes $=1, \mathrm{no}=0$ ) for company $\mathrm{j}$;

BCIN = The chairman of the board is an independent non-executive director (IND) (yes $=1, \mathrm{no}=0$ ) for company $\mathrm{j}$;

BI51 = More than half of the directors on the board are INDs $(y e s=1$, no=0) for company $\mathrm{j}$;

BIAL = More than three directors of the board are INDs (yes $=1$, no $=0$ ) for company $\mathrm{j}$;

BMAL = All directors on board to attend every board meeting (yes $=1$, no $=0$ ) for company $\mathrm{j}$;

BMA4 = Board's meetings more than four meetings a year $(y e s=1$, no $=0)$ for company $\mathrm{j}$;

BIAD = Internal audit department is in company (yes $=1$, no=0) for company $\mathrm{j}$;

ACCI = The chairman of AC is an IND (yes $=1$, no=0) for company $\mathrm{j}$;

IDAC = At least three AC members are INDs (yes $=1$, no=0) for company $\mathrm{j}$;

ACIN = All members of AC are INDs (yes $=1$, no=0) for company $\mathrm{j}$;

ACMA = All AC members to attend every board meeting (yes $=1$, no=0) for company $\mathrm{j}$;

ACA4 = AC's meetings more than four meetings a year (yes $=1$, no $=0$ ) for company $\mathrm{j}$;

$\mathrm{ACFL}=$ All AC members have financial literacy $(\mathrm{yes}=1$, no=0) for company $\mathrm{j}$;

$\mathrm{ACEX}=$ At least one $\mathrm{AC}$ member must be a financial expert (yes $=1$, no $=0$ ) for company $\mathrm{j}$;

RCCI = The chairman of RC is an IND (yes $=1, \mathrm{no}=0$ ) for company $\mathrm{j}$;

$\mathrm{RCPR}=$ Most members of RC are non-executive directors (NEDs) (yes $=1$, no $=0$ ) for company $\mathrm{j}$;

BOQI $_{i}=$ Board of director quality index, $0 \leq$ BOQI $_{j} \leq 1$ for company $\mathrm{j}$; Moderating Variables

$\mathrm{MV}_{\mathrm{ij}}=$ Moderating variables ( $\mathrm{i}=1$ and 2); MV1= TEXF and MV2=HLEX for company $\mathrm{j}$;

$=1$ for the companies with an executive director that has a family member and largest

TEXF $_{j} \quad$ shareholder involved, and 0 for the companies with an executive director that has no family member and largest shareholder involved for company $\mathrm{j}$;

$=1$ for the direct percentage of stock owned by executive directors which includes ownership

HLEX $_{\mathrm{j}}$ by his/her family member more than median with high ownership concentration, and 0 for lower than or equal to the median with low ownership concentration for company $\mathrm{j}$;

Interaction Terms of $\mathrm{MV}_{\mathrm{i}}$

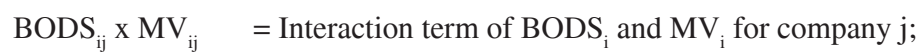

Control Variables

$\mathrm{PPM}_{\mathrm{j}} \quad$ = Income before extraordinary items (IBEX) over net sales for company $\mathrm{j}$;

$\mathrm{ROE}_{\mathrm{j}} \quad=$ IBEX over book value of equity for the beginning of the period for company $\mathrm{j}$;

$\mathrm{CR}_{\mathrm{j}}=$ Current assets over current liabilities for company $\mathrm{j}$;

$\mathrm{DE}_{\mathrm{j}} \quad$ = Long-term debt over book value of common equity for company $\mathrm{j}$;

LNTA $_{j}=$ Natural logarithm of total assets for company $\mathrm{j}$;

$\mathrm{CONG}=1$ if company is a conglomerate firm; $=0$ if company is a non-conglomerate firm for

${ }_{j}$ company $j$;

Parameters

BIG4 $_{j}=1$ if audit firm size is Big4; $=0$ if audit firm size is non-Big4 for company $\mathrm{j}$;

$\beta_{0}=$ Constant;

$\beta_{1-10}=$ Coefficients of variables 1 thru 10 ; and

$\varepsilon_{\mathrm{j}} \quad=$ Error term for company $\mathrm{j}$. 


\section{RESULTS}

Descriptive Statistics

\section{Level of Board of Directors Quality}

Table 7 presents the frequency of board of directors' quality which is first measurement in compliance with the SET's Code of Best Practice for Directors of Listed Companies, Best Practice Guidelines for Audit Committee, and The Fifteen Principles of Good Corporate Governance of nonfinancial listed companies in the Stock Exchange of Thailand (SET)-317 companies for the year 2004.

Table 7: Descriptive Statistics of Measurement of Each Dimensions of Board of Directors' Quality $(\mathrm{N}=317)$

\begin{tabular}{|c|c|c|c|}
\hline \multirow{2}{*}{ Acronym } & \multirow{2}{*}{$\begin{array}{l}\text { Independent Variables Compliance of Boards to } \\
\text { SET requirements }\end{array}$} & \multicolumn{2}{|c|}{ Companies Comply } \\
\hline & & Frequency & Percentage \\
\hline & 1. Quality of Board's Leadership Structure & & \\
\hline BCEO & $\begin{array}{l}\text { The titles and authority of the board's chairman and head of } \\
\text { management team are clearly separated }\end{array}$ & 186 & $58.7 \%$ \\
\hline $\mathrm{BCIN}$ & $\begin{array}{l}\text { The chairman of the board is an independent non-executive } \\
\text { director (IND) }\end{array}$ & 25 & $7.9 \%$ \\
\hline & 2. Quality of Board's Composition & & \\
\hline BI51 & More than half of the directors on the board are INDs & 10 & $3.2 \%$ \\
\hline BIAL & More than three directors of the board are INDs & 74 & $23.3 \%$ \\
\hline & 3. Quality of Board's Meetings & & \\
\hline BMAL & All directors on board to attend every board meetings & 18 & $5.7 \%$ \\
\hline BMA4 & Board's meetings more than 4 meetings a year & 249 & $78.5 \%$ \\
\hline BIAD & $\begin{array}{l}\text { 4. Quality of Board's Controlling System and Internal Audit } \\
\text { The existence of internal audit department is in company } \\
\text { 5. Quality of AC's Leadership Structure }\end{array}$ & 238 & $75.1 \%$ \\
\hline ACCI & $\begin{array}{l}\text { The chairman of AC is an IND } \\
6 . \text { Quality of AC's Composition }\end{array}$ & 283 & $89.3 \%$ \\
\hline IDAC & At least three AC members are INDs & 232 & $73.2 \%$ \\
\hline ACIN & All members of AC are INDs & 228 & $71.9 \%$ \\
\hline & 7. Quality of AC's Meetings & & \\
\hline ACMA & All AC members are to attend every AC meetings & 80 & $25.2 \%$ \\
\hline ACA4 & AC's meetings more than 4 meetings a year & 164 & $51.7 \%$ \\
\hline $\begin{array}{l}\text { ACFL } \\
\text { ACEX }\end{array}$ & $\begin{array}{l}\text { 8. Quality of AC's Knowledge and Expertise } \\
\text { All AC members have financial literacy } \\
\text { At least one AC member is a financial reporting expert as CPA }\end{array}$ & $\begin{array}{c}9 \\
54\end{array}$ & $\begin{array}{l}2.8 \% \\
17.0 \%\end{array}$ \\
\hline & 9. Quality of RC's Leadership Structure & & \\
\hline RCCI & $\begin{array}{l}\text { The chairman of RC is an IND } \\
\text { 10. Quality of RC's Composition }\end{array}$ & 34 & $10.7 \%$ \\
\hline RCPR & $\begin{array}{l}\text { More than half of the RC members are non-executive directors } \\
\text { Board of Directors' Quality Index }\end{array}$ & 68 & $21.5 \%$ \\
\hline BOQI & Sum of Frequency $=16$ CGs $\times 317$ companies $=5,072$ & 1,952 & $\begin{array}{c}38.5 \% \\
(1,952 / 5,072)\end{array}$ \\
\hline
\end{tabular}

Table 8 provides correlation matrix of control and independent variables. 


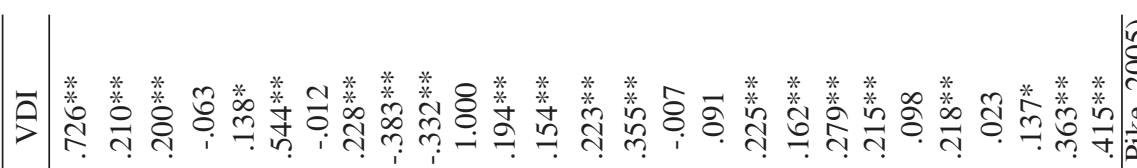
糸

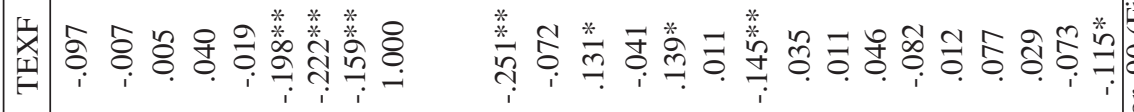

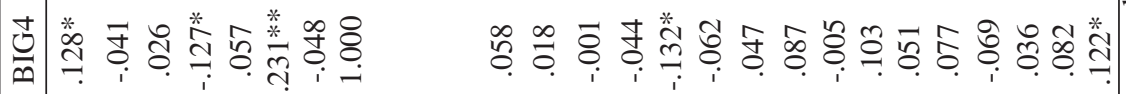

ర

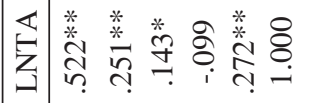

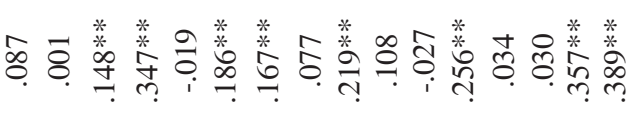

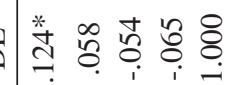

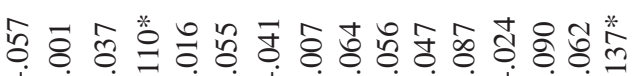

임

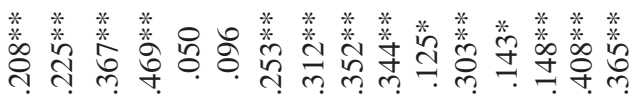




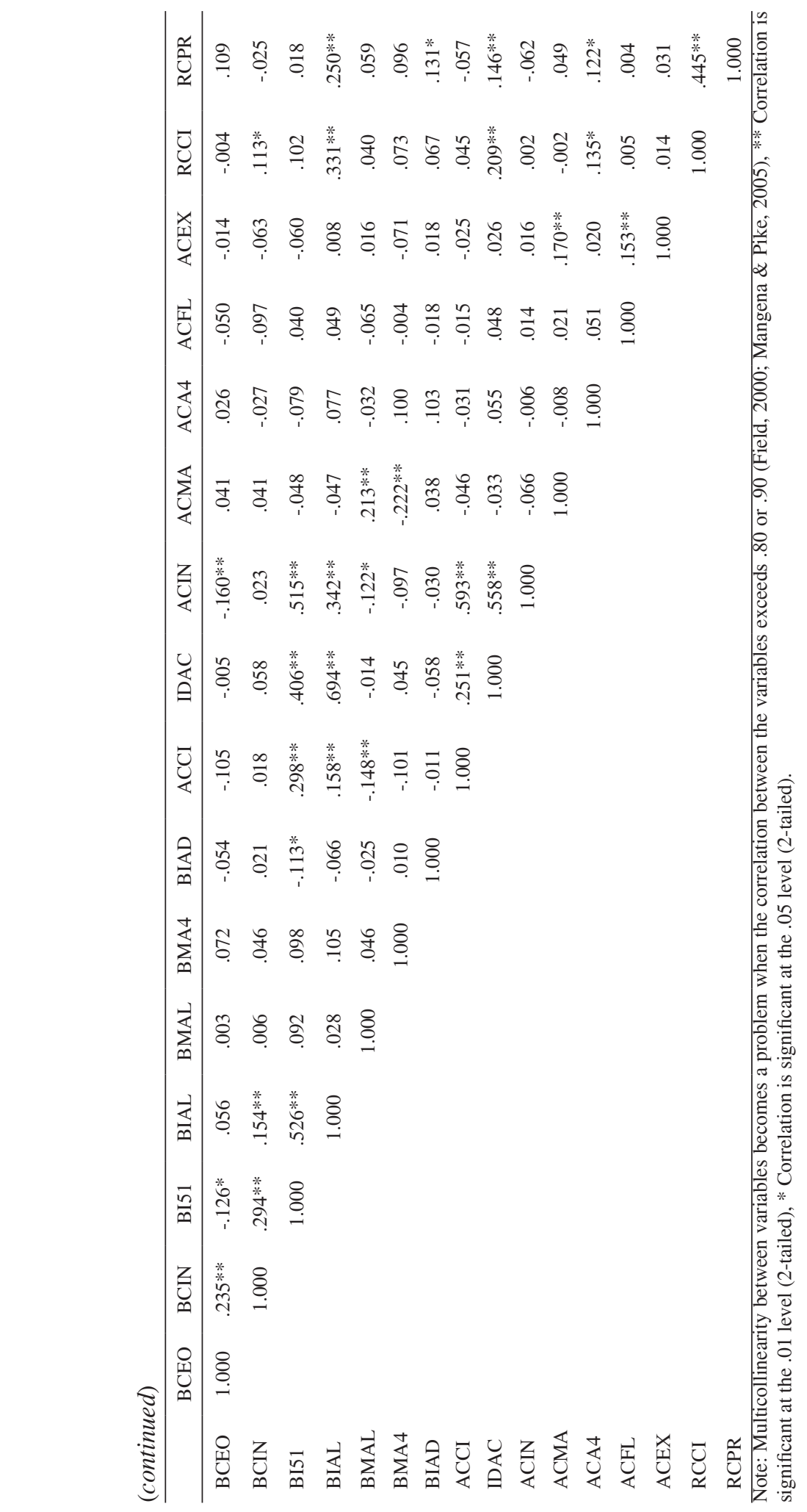




\section{Descriptive Statistics}

Table 9 provides descriptive statistics of dependent, control, and moderating variables.

Table 9: Descriptive Statistics of Dependent, Control, and Moderator Variables

\begin{tabular}{|c|c|c|c|}
\hline Variables & Acronym & Mean & $\mathrm{SD}$ \\
\hline \multicolumn{4}{|l|}{ Dependent Variable } \\
\hline Voluntary disclosure index & VDI & 0.37 & .11 \\
\hline \multicolumn{4}{|l|}{ Control Variables } \\
\hline Income before extraordinary items over net sales & PPM & 0.09 & .20 \\
\hline IBEX over book value of equity for the beginning of the period & ROE & 0.17 & .47 \\
\hline Current assets over current liabilities & $\mathrm{CR}$ & 2.50 & 3.18 \\
\hline Long-term debt over book value of common equity & $\mathrm{DE}$ & 0.36 & 1.27 \\
\hline \multirow[t]{2}{*}{ Natural logarithm of total assets } & LNTA & 3.44 & 1.36 \\
\hline & & Frequency & Percentage \\
\hline Scope of business operations & CONG & & \\
\hline - Company is a conglomerate firm & 1 & 41 & $12.9 \%$ \\
\hline - Company is not a conglomerate firm & 0 & 276 & $87.1 \%$ \\
\hline Audit firm size influence & BIG4 & & \\
\hline - $\quad$ Audit firm size is Big4 & 1 & 197 & $62.1 \%$ \\
\hline - Audit firm size is not Big4 & 0 & 120 & $37.9 \%$ \\
\hline Moderating Variables & Mean & Median & $\mathrm{SD}$ \\
\hline Percentage of stock owned by executive directors which & 0.17 & 0.08 & .19 \\
\hline & Acronym & Frequency & Percentage \\
\hline Type of an executive director & TEXF & & \\
\hline - Family member, largest shareholder & 1 & 137 & $43.2 \%$ \\
\hline - Non-family member, largest shareholder & 0 & 180 & $56.8 \%$ \\
\hline Executive directors' ownership & HLEX & & \\
\hline - High Concentration (More than median at 8\%) & 1 & 154 & $48.6 \%$ \\
\hline - Low Concentration (At most median at $8 \%$ ) & 0 & 163 & $51.4 \%$ \\
\hline
\end{tabular}

\section{Goodness of Measures}

This section describes the study's voluntary disclosure checklist and provide evidence supporting its reliability.

\section{Cronbach's Alpha for Reliability Test}

The reliability of measurement in this study was tested using Cronbach's alpha (Cronbach, 1951). The test is based on the average correlation among items (Nunnally \& Bernstein, 1994). The logic behind the test is that if the inter-correlations among the items are high, the items will measure the same underlying construct. This study used a Cronbach's alpha coefficient of .60 to .70 or higher which indicates that there is an internal consistency in the disclosure scores. Hair, Anderson, Tatham and Black, (1998), Liouville and Bayad (1998), and Sureshchandar, Rajendran and Anantharaman, (2002) stated that alpha less than .60 is considered poor, .70 is acceptable; meanwhile, alpha over .80 is considered to be good.

Table 10 presents the Cronbach's Alpha for each variable of voluntary disclosure items of non-financial listed companies in the Stock Exchange of Thailand's (SET)-317 companies for the year 2004 .

As seen from Table 10, the instruments and voluntary disclosure checklist items, used in the study were reliable, with coefficients ranging from .65 to .86 , which exceeded the minimum acceptance level of .60 . 
Table 10: Reliability Coefficients of Voluntary Disclosure Items (N=317)

\begin{tabular}{lccc}
\hline \multicolumn{1}{c}{ Voluntary Disclosure items } & $\begin{array}{c}\text { Cronbach's } \\
\text { Alpha } \\
\text { Value }\end{array}$ & $\begin{array}{c}\text { Number of } \\
\text { Items }\end{array}$ & $\begin{array}{c}\text { Number of } \\
\text { Cases Deleted }\end{array}$ \\
\hline $\begin{array}{l}\text { A. Strategic information - Adjusted for items that } \\
\text { are not applicable to the firm }\end{array}$ & .65 & 16 & - \\
$\begin{array}{l}\text { B. Non-financial information - Adjusted for items } \\
\text { that are not applicable to the firm }\end{array}$ & .74 & 27 & 1 \\
$\begin{array}{l}\text { C. Financial information - Adjusted for items that } \\
\text { are not applicable to the firm }\end{array}$ & .67 & 27 & 2 \\
$\begin{array}{l}\text { D. All information - Adjusted for items that are } \\
\text { not applicable to the firm (VDI) }\end{array}$ & .86 & 70 & 1 \\
\hline
\end{tabular}

\section{THE HIERARCHICAL REGRESSION RESULTS AND DISCUSSION}

Hypothesis Testing

\section{Statistics Tool using Hierarchical Regression Analysis}

\section{Multicollinearity Testing from Variance Inflation Factor (VIF)}

Ordinary least square (OLS) regression models assume that there is no intercorrelation among the independent variables, i.e. there is no multicollinearity. To further ensure that there is no multicollinearity problem, after the variables were dropped, another method for detecting multicollinearity which involves the calculation of the variance inflation factor (VIF) was conducted. VIF measures the degree to which each explanatory variable is explained by the other explanatory variables. Very large VIF values indicate high collinearity. VIF values above 10 or Tolerance value less than .10 (Hair et al., 1998) indicates absence of multicollinearity. In this study, VIF figures for all the independent variables were well below 10 and Tolerance were more than .10. This indicated absenced of multicollinearity problems and confirmed that the method of eliminating the variables with multicollinearity problems were successful. The results of the Tolerance of variables are summarised in each table of Hierarchical regression analysis while the details of SPSS output are in Appendix 9.

\begin{abstract}
Autocorrelation Testing from Durbin-Watson
Ordinary least square (OLS) regression models assume that independence of error terms $\left(\varepsilon_{\mathrm{j}}\right)$, i.e. one error term is not affected by another error term. When they are not, then there is autocorrelation. Autocorrelation is usually associated with time series data. The Durbin-Watson test is a widely used method of testing for autocorrelation. Thus, this study used the Durbin-Watson test to detecting autocorrelation. A Durbin-Watson value between 1.65 and 2.35 confirmed the absence of autocorrelation (Prasith-rathsint, 2005). The results of the Durbin-Watson are summarised in each table of hierarchical regression analysis while the details of SPSS output are in Appendix 9. The figures show absence of autocorrelation as the figures are within the acceptable threshold.
\end{abstract}

\section{Hierarchical Regression Results}

From Hierarchical Regression results the effects of control variables on dependent variables can be answered using the output from step 1, the effects of independent variables on dependent variables can be answered using the output from step 2, and moderating role of moderating variables on relationship between independent variables and dependent variables can be answered using the output from step 3 and step 4 . 
Table 11: Hierarchical Regression Results (N=317)

\begin{tabular}{|c|c|c|c|c|c|c|}
\hline \multirow{5}{*}{ Variables } & \multicolumn{6}{|c|}{ Standardised Beta } \\
\hline & \multirow{4}{*}{$\begin{array}{l}\text { Step 1 } \\
\text { CV } \\
(1)-(7)\end{array}$} & \multirow{4}{*}{$\begin{array}{l}\text { Step } 2 \\
\text { (1) }\end{array}$} & \multirow{2}{*}{\multicolumn{2}{|c|}{$\frac{\text { Step } 3}{\text { Model }}$}} & \multirow{2}{*}{\multicolumn{2}{|c|}{$\begin{array}{l}\text { Step } 4 \\
\text { Model }\end{array}$}} \\
\hline & & & & & & \\
\hline & & & 1.1 & 1.2 & 1.1 & 1.2 \\
\hline & & & TEXF & HLEX & TEXF & HLEX \\
\hline Control Variables & & & & & & \\
\hline PPM & .059 & .059 & .067 & .070 & .065 & .067 \\
\hline ROE & $.105^{*}$ & .091 & $.100 *$ & $.117^{*}$ & $.102 *$ & $.121^{*}$ \\
\hline $\mathrm{CR}$ & -.021 & -.018 & -.026 & -.036 & -.030 & -.040 \\
\hline $\mathrm{DE}$ & .001 & .012 & .020 & .021 & .025 & .027 \\
\hline LNTA & $.486^{* *}$ & $.475^{* *}$ & $.427 * *$ & $.423 * *$ & $.423 * *$ & $.417 * *$ \\
\hline CONG & -.012 & -.026 & -.085 & -.081 & -.087 & -.081 \\
\hline BIG4 & $.112 *$ & $.106^{*}$ & .071 & .082 & .071 & .088 \\
\hline Independent Variable & & & & & & \\
\hline BCEO & & $.136^{* *}$ & .074 & .087 & $.136^{*}$ & $.169^{*}$ \\
\hline Moderating Variable & & & & & & \\
\hline MV & & & $-.286^{* *}$ & $-.235 * *$ & $-.213^{* *}$ & -.144 \\
\hline Interaction Terms & & & & & & \\
\hline BCEO x MV & & & & & -.105 & -.130 \\
\hline $\begin{array}{l}\text { Statistics } \\
\text { R Square }\end{array}$ & .325 & .343 & .412 & 388 & 416 & 393 \\
\hline Adjusted R Square & .310 & .326 & .395 & .370 & .397 & .373 \\
\hline R Square Change & .325 & .018 & .070 & .045 & .004 & .005 \\
\hline F Change & $21.243^{* *}$ & $8.288^{* *}$ & $36.321 * *$ & $22.562 * *$ & 2.078 & 2.638 \\
\hline Durbin-Watson & & & & & 1.806 & 1.823 \\
\hline Tolerance Min/Max & & & & & $.894 / .963$ & $.858 / .963$ \\
\hline Control Variables & & & & & & \\
\hline PPM & .059 & .063 & .071 & .074 & .070 & .072 \\
\hline ROE & $.105^{*}$ & .090 & $.096^{*}$ & $.114 *$ & $.098^{*}$ & $.117^{*}$ \\
\hline $\mathrm{CR}$ & -.021 & -.018 & -.026 & -.037 & -.026 & -.037 \\
\hline $\mathrm{DE}$ & .001 & -.001 & .013 & .013 & .013 & .014 \\
\hline LNTA & $.486^{* *}$ & $.488 * *$ & $.433 * *$ & $.429 * *$ & $.431^{* *}$ & $.425^{* *}$ \\
\hline CONG & -.012 & -.002 & -.071 & -.066 & -.070 & -.064 \\
\hline BIG4 & $.112 *$ & $.111 *$ & .073 & .083 & .073 & .086 \\
\hline Independent Variable & & & & & & \\
\hline $\mathrm{BCIN}$ & & $.142 * *$ & $.116 * *$ & $.121 * *$ & $.132 *$ & $.151 * *$ \\
\hline Moderating Variable & & & & & & \\
\hline $\begin{array}{l}\text { MV } \\
\text { Interaction Terms }\end{array}$ & & & $-.292^{* *}$ & $-.243^{* *}$ & $-.286^{* *}$ & $-.233^{* *}$ \\
\hline BCIN x MV & & & & & -.028 & -.048 \\
\hline Statistics & & & & & & \\
\hline R Square & .325 & .345 & .420 & .395 & .421 & .396 \\
\hline Adjusted R Square & .310 & 328 & .403 & .377 & .402 & .377 \\
\hline R Square Change & .325 & .020 & .075 & .050 & .001 & .001 \\
\hline F Change & $21.243 * *$ & $9.368 * *$ & $39.966 * *$ & $25.464 * *$ & 268 & .666 \\
\hline Durbin-Watson & & & & & 1.751 & 1.762 \\
\hline Tolerance Min/Max & & & & & $.894 / .985$ & $.858 / .985$ \\
\hline
\end{tabular}


(continued)

\begin{tabular}{|c|c|c|c|c|c|c|}
\hline Control Variables & & & & & & \\
\hline PPM & .059 & .057 & .067 & .070 & .066 & .068 \\
\hline ROE & $.105^{*}$ & $.115^{*}$ & $.120 * *$ & $.138 * *$ & $.120 * *$ & $.138 * *$ \\
\hline CR & -.021 & -.022 & -.031 & -.041 & -.028 & -.037 \\
\hline $\mathrm{DE}$ & .001 & .001 & .016 & .015 & .018 & .018 \\
\hline LNTA & $.486^{* * *}$ & $.458 * *$ & $.391 * *$ & $.395 * *$ & $.390 * *$ & $.393 * *$ \\
\hline CONG & -.012 & .031 & -.034 & -.034 & -.031 & -.029 \\
\hline BIG4 & $.112 *$ & $.121 *$ & .079 & $.091 *$ & .081 & $.092 *$ \\
\hline Independent Variable & & & & & & \\
\hline BI51 & & $.163 * *$ & $.198 * *$ & $.168 * *$ & $.221 * *$ & $.194 * *$ \\
\hline Moderating Variable & & & & & & \\
\hline MV & & & $-.325 * *$ & $-.259 * *$ & $-.249^{*}$ & -.183 \\
\hline Interaction Terms & & & & & & \\
\hline BI51 x MV & & & & & -.086 & -.085 \\
\hline Statistics & & & & & & \\
\hline R Square & .325 & .349 & .442 & .406 & .443 & .407 \\
\hline Adjusted R Square & .310 & .332 & .426 & .389 & .425 & .388 \\
\hline R Square Change & .325 & .024 & .093 & .058 & .001 & .001 \\
\hline F Change & $21.243 * *$ & $11.344 * *$ & $51.369 * *$ & $29.774 * *$ & .421 & .404 \\
\hline Durbin-Watson & & & & & 1.730 & 1.760 \\
\hline Tolerance Min/Max & & & & & $.894 / .910$ & $.858 / .908$ \\
\hline
\end{tabular}

$* \mathrm{p}<.05, * * \mathrm{p}<.01$

(continued)

\begin{tabular}{|c|c|c|c|c|c|c|}
\hline \multirow{5}{*}{ Variables } & \multicolumn{6}{|c|}{ Standardised Beta } \\
\hline & \multirow{4}{*}{$\begin{array}{c}\text { Step } 1 \\
\text { CV } \\
(1)-(7)\end{array}$} & \multirow{4}{*}{$\begin{array}{c}\text { Step } 2 \\
\text { (1) }\end{array}$} & \multirow{2}{*}{\multicolumn{2}{|c|}{$\frac{\text { Step } 3}{\text { Model }}$}} & \multirow{2}{*}{\multicolumn{2}{|c|}{$\frac{\text { Step } 4}{\text { Model }}$}} \\
\hline & & & & & & \\
\hline & & & 1.1 & 1.2 & 1.1 & 1.2 \\
\hline & & & TEXF & HLEX & TEXF & HLEX \\
\hline Control Variables & & & & & & \\
\hline PPM & .059 & .067 & .076 & .078 & .077 & .076 \\
\hline ROE & $.105^{*}$ & $.110^{*}$ & $.114 *$ & $.131 * *$ & $.113^{*}$ & $.128 * *$ \\
\hline $\mathrm{CR}$ & -.021 & -.033 & -.040 & -.049 & -.041 & -.049 \\
\hline $\mathrm{DE}$ & .001 & -.003 & .011 & .011 & .010 & .009 \\
\hline LNTA & $.486^{* *}$ & $.401 * *$ & $.345^{* *}$ & $.352 * *$ & $.343 * *$ & $.342 * *$ \\
\hline CONG & -.012 & .003 & -.066 & -.059 & -.064 & -.054 \\
\hline BIG4 & $.112 *$ & $.141^{* *} *$ & $.101 *$ & $.111^{*}$ & $.103 *$ & $.111 *$ \\
\hline Independent Variable & & & & & & \\
\hline BIAL & & $.216^{* * *}$ & $.215^{* *}$ & $.196^{* * *}$ & $.240 * *$ & $.267 * *$ \\
\hline Moderating Variable & & & & & & \\
\hline MV & & & $-.303^{* *}$ & $-.239 * *$ & -.198 & -.004 \\
\hline Interaction Terms & & & & & 112 & 250 \\
\hline BIAL x MV & & & & & -.112 & -.250 \\
\hline Statistics & & & & & & \\
\hline R Square & .325 & .365 & .446 & .413 & .448 & .420 \\
\hline Adjusted R Square & .310 & .348 & .430 & .396 & .430 & .401 \\
\hline R Square Change & .325 & .040 & .082 & .049 & .001 & .007 \\
\hline F Change & $21.243 * *$ & $19.232 * *$ & $45.436 * *$ & $25.387 * *$ & 678 & 3.478 \\
\hline Durbin-Watson & & & & & 1.730 & 1.737 \\
\hline Tolerance Min/Max & & & & & $.853 / .923$ & $.853 / .895$ \\
\hline
\end{tabular}


(continued)

\begin{tabular}{|c|c|c|c|c|c|c|}
\hline Control Variables & & & & & & \\
\hline PPM & .059 & .058 & .067 & .071 & .066 & .070 \\
\hline ROE & $.105^{*}$ & $.105^{*}$ & $.108 *$ & $.129 * *$ & $.107 *$ & $.129 * *$ \\
\hline CR & -.021 & -.021 & -.029 & -.041 & -.028 & -.039 \\
\hline $\mathrm{DE}$ & .001 & .000 & .014 & .014 & .018 & .019 \\
\hline LNTA & $.486 * *$ & $.486 * *$ & $.429 * *$ & $.423 * *$ & $.427 * *$ & $.421 * *$ \\
\hline CONG & -.012 & -.010 & -.077 & -.073 & -.075 & -.072 \\
\hline BIG4 & $.112 *$ & $.114 *$ & .078 & .088 & .078 & .092 \\
\hline Independent Variable & & & & & & \\
\hline $\begin{array}{l}\text { BMAL } \\
\text { Moderating Variable }\end{array}$ & & .014 & .043 & .042 & .070 & .083 \\
\hline MV & & & $-.308 * *$ & $-.260 * *$ & -.033 & .085 \\
\hline $\begin{array}{l}\text { Interaction Terms } \\
\text { BMAL x MV } \\
\text { Statistics }\end{array}$ & & & & & -.282 & -.357 \\
\hline R Square & .325 & .325 & .409 & .382 & .410 & .384 \\
\hline Adjusted R Square & .310 & .308 & .392 & .364 & .391 & .364 \\
\hline R Square Change & .325 & .000 & .084 & .057 & .001 & .002 \\
\hline F Change & $21.243 * *$ & .087 & $43.506^{* * *}$ & $28.491 * *$ & .636 & 1.008 \\
\hline Durbin-Watson & & & & & 1.773 & 1.790 \\
\hline Tolerance Min/Max & & & & & $.890 / .966$ & $.858 / .966$ \\
\hline Control Variables & & & & & & \\
\hline PPM & .059 & .059 & .069 & .071 & .069 & .071 \\
\hline ROE & $.105^{*}$ & $.105^{*}$ & $.108^{*}$ & $.128 * *$ & $.109^{*}$ & $.130 * *$ \\
\hline $\mathrm{CR}$ & -.021 & -.021 & -.028 & -.040 & -.029 & -.037 \\
\hline $\mathrm{DE}$ & .001 & .001 & .015 & .015 & .014 & .016 \\
\hline LNTA & $.486^{* *}$ & $.485^{* *}$ & $.426 * *$ & $.425^{* *}$ & $.424 * *$ & $.419 * *$ \\
\hline CONG & -.012 & -.012 & -.081 & -.077 & -.082 & -.077 \\
\hline BIG4 & $.112 *$ & $.113^{*}$ & .074 & .083 & .076 & .089 \\
\hline Independent Variable & & & & & & \\
\hline BMA4 & & .003 & .014 & -.002 & .055 & .064 \\
\hline Moderating Variable & & & & & & \\
\hline MV & & & $-.304 * *$ & $-.255 * *$ & $-.219^{*}$ & -.125 \\
\hline Interaction Terms & & & & & & \\
\hline BMA4 x MV & & & & & -.103 & -.156 \\
\hline Statistics & & & & & & \\
\hline R Square & .325 & .325 & .407 & .381 & .409 & .385 \\
\hline Adjusted R Square & .310 & .307 & .390 & .363 & .390 & .364 \\
\hline R Square Change & .325 & .000 & .082 & .056 & .002 & .004 \\
\hline F Change & $21.243 * *$ & .004 & $42.665 * *$ & $27.658 * *$ & .871 & 1.906 \\
\hline Durbin-Watson & & & & & 1.770 & 1.787 \\
\hline Tolerance Min/Max & & & & & $.894 / .949$ & $.858 / .949$ \\
\hline
\end{tabular}

$* \mathrm{p}<.05, * * \mathrm{p}<.01$ 
(continued)

\begin{tabular}{|c|c|c|c|c|c|c|}
\hline \multirow{5}{*}{ Variables } & \multicolumn{6}{|c|}{ Standardised Beta } \\
\hline & \multirow{4}{*}{$\begin{array}{c}\text { Step } 1 \\
\text { CV } \\
(1)-(7)\end{array}$} & \multirow{4}{*}{$\begin{array}{c}\text { Step } 2 \\
\text { (1) }\end{array}$} & \multicolumn{2}{|c|}{ Step 3} & \multicolumn{2}{|c|}{ Step 4} \\
\hline & & & \multicolumn{2}{|c|}{ Model } & \multicolumn{2}{|c|}{ Model } \\
\hline & & & 1.1 & 1.2 & 1.1 & 1.2 \\
\hline & & & TEXF & HLEX & TEXF & HLEX \\
\hline Control Variables & & & & & & \\
\hline PPM & .059 & .052 & .063 & .065 & .063 & .065 \\
\hline ROE & $.105^{*}$ & .095 & $.101 *$ & $.118^{*}$ & $.100 *$ & $.118 *$ \\
\hline $\mathrm{CR}$ & -.021 & -.006 & -.017 & -.026 & -.017 & -.026 \\
\hline DE & .001 & .012 & .023 & .025 & .023 & .025 \\
\hline LNTA & $.486^{* *}$ & $.467 * *$ & $.418 * *$ & $.408 * *$ & $.417 * *$ & $.408 * *$ \\
\hline CONG & -.012 & -.014 & -.080 & -.078 & -.081 & -.078 \\
\hline BIG4 & $.112 *$ & $.112^{*}$ & .074 & .083 & .073 & .083 \\
\hline Independent Variable & & & & & & \\
\hline BIAD & & $.125 * *$ & $.092 *$ & $.116^{*}$ & .087 & .116 \\
\hline Moderating Variable & & & & & & \\
\hline $\begin{array}{l}\text { MV } \\
\quad \text { Interaction Terms }\end{array}$ & & & $-.292 * *$ & $-.250 * *$ & $-.302 * *$ & $-.250 * *$ \\
\hline BIAD x MV & & & & & .012 & .000 \\
\hline Statistics & & & & & & \\
\hline R Square & .325 & .340 & .415 & .393 & .415 & .393 \\
\hline Adjusted R Square & .310 & .323 & .398 & .375 & .396 & .373 \\
\hline R Square Change & .325 & .015 & .075 & .054 & .000 & .000 \\
\hline F Change & $21.243 * *$ & $6.914 * *$ & $39.508 * *$ & $27.101 * *$ & .015 & .000 \\
\hline Durbin-Watson & & & & & 1.771 & 1.798 \\
\hline Tolerance Min/Max & & & & & $.894 / .958$ & $.858 / .941$ \\
\hline Control Variables & & & & & & \\
\hline PPM & .059 & .064 & .074 & .077 & .075 & .080 \\
\hline ROE & $.105^{*}$ & $.114 *$ & $.119 *$ & $.138 * *$ & $.118^{*}$ & $.134 * *$ \\
\hline $\mathrm{CR}$ & -.021 & -.010 & -.016 & -.028 & -.011 & -.020 \\
\hline $\mathrm{DE}$ & .001 & .004 & .019 & .019 & .019 & .018 \\
\hline LNTA & $.486 * *$ & $.476^{* *}$ & $.416^{* *}$ & $.412 * *$ & $.419 * *$ & $.415^{* *}$ \\
\hline CONG & -.012 & -.012 & -.083 & -.078 & -.084 & -.075 \\
\hline BIG4 & $.112^{*}$ & $.105^{*}$ & .062 & .074 & .063 & .074 \\
\hline Independent Variable & & & & & & \\
\hline ACCI & & $.129 * *$ & $.149 * *$ & $.137 * *$ & $.186^{* *}$ & $.193^{* *}$ \\
\hline Moderating Variable & & & & & & \\
\hline $\begin{array}{l}\text { MV } \\
\quad \text { Interaction Terms }\end{array}$ & & & $-.314 * *$ & $-.260 * *$ & -.177 & -.098 \\
\hline ACCI x MV & & & & & -.150 & -.178 \\
\hline Statistics & & & & & & \\
\hline R Square & .325 & .341 & .429 & .399 & .431 & .402 \\
\hline Adjusted R Square & .310 & .324 & .412 & .381 & .412 & .382 \\
\hline R Square Change & .325 & .016 & .088 & .058 & .002 & .003 \\
\hline F Change & $21.243 * *$ & $7.501 * *$ & $47.047 * *$ & $29.603 * *$ & 1.134 & 1.526 \\
\hline Durbin-Watson & & & & & 1.808 & 1.806 \\
\hline Tolerance Min/Max & & & & & $.894 / .972$ & $.858 / .972$ \\
\hline
\end{tabular}


(continued)

\begin{tabular}{|c|c|c|c|c|c|c|}
\hline \multicolumn{7}{|l|}{ Control Variables } \\
\hline PPM & .059 & .063 & .072 & .075 & .072 & .070 \\
\hline ROE & $.105^{*}$ & $.116^{*}$ & $.121 * *$ & $.139 * *$ & $.121 * *$ & $.139 * *$ \\
\hline $\mathrm{CR}$ & -.021 & -.037 & -.046 & -.055 & -.046 & -.052 \\
\hline DE & .001 & .001 & .015 & .015 & .015 & .016 \\
\hline LNTA & $.486^{* *}$ & $.439 * *$ & $.376 * *$ & $.379 * *$ & $.376^{* *}$ & $.370 * *$ \\
\hline CONG & -.012 & -.014 & -.086 & -.078 & -.086 & -.078 \\
\hline BIG4 & $.112^{*}$ & $.122 *$ & .081 & $.093^{*}$ & .081 & .085 \\
\hline Independent Variable & & & & & & \\
\hline $\begin{array}{l}\text { IDAC } \\
\text { Moderating Variable }\end{array}$ & & $.187 * *$ & $.204 * *$ & $.184 * *$ & $.203 * *$ & $.268 * *$ \\
\hline $\begin{array}{l}\text { MV } \\
\text { Interaction Terms }\end{array}$ & & & $-.315 * *$ & $-.253 * *$ & -.320 & .079 \\
\hline $\begin{array}{l}\text { IDAC x MV } \\
\text { Statistics }\end{array}$ & & & & & .005 & -.350 \\
\hline R Square & .325 & .358 & .446 & .412 & .446 & .419 \\
\hline Adjusted R Square & .310 & .341 & .430 & .395 & .428 & .400 \\
\hline R Square Change & .325 & .033 & .088 & .055 & .000 & .007 \\
\hline F Change & $21.243 * *$ & $15.662 * *$ & $49.010 * *$ & $28.696^{* *}$ & .001 & 3.564 \\
\hline $\begin{array}{l}\text { Durbin-Watson } \\
\text { Tolerance Min/Max }\end{array}$ & & & & & $\begin{array}{c}1.709 \\
.894 / .939\end{array}$ & $\begin{array}{c}1.705 \\
.858 / .939\end{array}$ \\
\hline
\end{tabular}

$* \mathrm{p}<.05, * * \mathrm{p}<.01$

(continued)

\begin{tabular}{|c|c|c|c|c|c|c|}
\hline \multirow{5}{*}{ Variables } & \multicolumn{6}{|c|}{ Standardised Beta } \\
\hline & \multirow{4}{*}{$\begin{array}{l}\text { Step } 1 \\
\text { CV } \\
(1)-(7)\end{array}$} & \multirow{4}{*}{$\begin{array}{l}\text { Step } 2 \\
(1)\end{array}$} & \multicolumn{2}{|c|}{ Step 3} & \multicolumn{2}{|c|}{ Step 4} \\
\hline & & & \multicolumn{2}{|c|}{ Model } & \multicolumn{2}{|c|}{ Model } \\
\hline & & & 1.1 & 1.2 & 1.1 & 1.2 \\
\hline & & & TEXF & HLEX & TEXF & HLEX \\
\hline \multicolumn{7}{|l|}{ Control Variables } \\
\hline PPM & .059 & .071 & .082 & .084 & .082 & .085 \\
\hline ROE & $.105^{*}$ & $.114 *$ & $.119 *$ & $.138 * *$ & $.119 *$ & $.134^{* *}$ \\
\hline $\mathrm{CR}$ & -.021 & -.014 & -.021 & -.033 & -.020 & -.025 \\
\hline $\mathrm{DE}$ & .001 & -.003 & .011 & .012 & .011 & .009 \\
\hline LNTA & $.486 * *$ & $.468 * *$ & $.406 * *$ & $.404 * *$ & $.407 * *$ & $.406 * *$ \\
\hline CONG & -.012 & -.007 & -.079 & -.073 & -.079 & -.070 \\
\hline BIG4 & $.112 *$ & $.101 *$ & .057 & .070 & .057 & .067 \\
\hline Independent Variable & & & & & & \\
\hline $\begin{array}{l}\text { ACIN } \\
\text { Moderating Variable }\end{array}$ & & $.166 * *$ & $.190 * *$ & $.175^{* *}$ & $.198 * *$ & $.224 * *$ \\
\hline MV & & & $-.319 * *$ & $-.262 * *$ & -.281 & -.078 \\
\hline $\begin{array}{l}\text { Interaction Terms } \\
\text { ACIN x MV } \\
\text { Statistics }\end{array}$ & & & & & -.040 & -.194 \\
\hline R Square & .325 & .351 & .442 & .410 & .442 & .412 \\
\hline Adjusted R Square & .310 & .335 & .425 & .393 & .424 & .393 \\
\hline R Square Change & .325 & .027 & .090 & .059 & .000 & .002 \\
\hline F Change & $21.243 * *$ & $12.610 * *$ & $49.690 * *$ & $30.627 * *$ & .046 & .959 \\
\hline Durbin-Watson & & & & & 1.709 & 1.713 \\
\hline Tolerance Min/Max & & & & & $.894 / .967$ & $.858 / .967$ \\
\hline
\end{tabular}




\section{(continued)}

\begin{tabular}{|c|c|c|c|c|c|c|}
\hline Control Variables & & & & & & \\
\hline PPM & .059 & .055 & .065 & .068 & .065 & .067 \\
\hline ROE & $.105 *$ & $.103 *$ & $.107 *$ & $.125 *$ & $.107 *$ & $.126^{*}$ \\
\hline $\mathrm{CR}$ & -.021 & -.014 & -.023 & -.033 & -.023 & -.033 \\
\hline $\mathrm{DE}$ & .001 & -.005 & .010 & .010 & .011 & .011 \\
\hline LNTA & $.486^{* * *}$ & $.494 * *$ & $.437 * *$ & $.433 * *$ & $.436^{* *} *$ & $.433 * *$ \\
\hline CONG & -.012 & -.007 & -.076 & -.071 & -.076 & -.072 \\
\hline BIG4 & $.112 *$ & $.107 *$ & .069 & .079 & .070 & .079 \\
\hline Independent Variable & & & & & & \\
\hline ACMA & & $.101 *$ & .073 & $.090 *$ & .057 & .071 \\
\hline Moderating Variable & & & & & & \\
\hline MV & & & $-.296^{* *}$ & $-.251 * *$ & -.381 & -.349 \\
\hline Interaction Terms & & & & & & \\
\hline ACMA $\times$ MV & & & & & .086 & .100 \\
\hline Statistics & & & & & & \\
\hline R Square & .325 & .335 & .412 & .389 & .412 & .389 \\
\hline Adjusted R Square & .310 & .318 & .395 & .371 & .393 & .369 \\
\hline R Square Change & .325 & .010 & .077 & .054 & .000 & .000 \\
\hline F Change & $21.243^{* *}$ & $4.658^{*}$ & $40.373^{* *}$ & $26.992 * *$ & .072 & .086 \\
\hline Durbin-Watson & & & & & 1.783 & 1.809 \\
\hline Tolerance Min/Max & & & & & $.894 / .985$ & $.858 / .985$ \\
\hline Control Variables & & & & & & \\
\hline PPM & .059 & .061 & .071 & .074 & .071 & .074 \\
\hline ROE & $.105^{*}$ & .100 & $.101^{*}$ & $.122 *$ & $.100^{*}$ & $.122 *$ \\
\hline $\mathrm{CR}$ & -.021 & -.023 & -.032 & -.043 & -.032 & -.043 \\
\hline $\mathrm{DE}$ & .001 & -.001 & .013 & .013 & .012 & .013 \\
\hline LNTA & $.486^{* * *}$ & $.467 * *$ & $.402 * *$ & $.399 * *$ & $.403^{* *}$ & $.399 * *$ \\
\hline CONG & -.012 & -.019 & $-.092 *$ & -.088 & $-.093 *$ & -.088 \\
\hline hBIG4 & $.112 *$ & $.110^{*}$ & .068 & .079 & .070 & .080 \\
\hline $\begin{array}{l}\text { Independent Variable } \\
\text { ACA4 } \\
\text { Moderating Variable }\end{array}$ & & .078 & $.106^{*}$ & $.100 *$ & .120 & .106 \\
\hline MV & & & $-.313 * *$ & $-.264 * *$ & $-.288 * *$ & $-.255^{*}$ \\
\hline Interaction Terms & & & & & & \\
\hline $\begin{array}{l}\text { ACA4 x MV } \\
\text { Statistics }\end{array}$ & & & & & -.031 & -.012 \\
\hline R Square & .325 & .330 & .417 & .390 & .417 & .390 \\
\hline Adjusted R Square & .310 & .313 & .400 & .372 & .398 & .370 \\
\hline R Square Change & .325 & .006 & .087 & .059 & .000 & .000 \\
\hline F Change & $21.243^{* *}$ & 2.574 & $45.741 * *$ & $29.875^{* *}$ & .069 & .009 \\
\hline Durbin-Watson & & & & & 1.787 & 1.796 \\
\hline Tolerance Min/Max & & & & & $.894 / .967$ & $.858 / .944$ \\
\hline
\end{tabular}

$* \mathrm{p}<.05, * * \mathrm{p}<.01$ 
(continued)

\begin{tabular}{|c|c|c|c|c|c|c|}
\hline \multirow{5}{*}{ Variables } & \multicolumn{6}{|c|}{ Standardised Beta } \\
\hline & \multirow{4}{*}{$\begin{array}{c}\text { Step } 1 \\
\text { CV } \\
(1)-(7)\end{array}$} & \multirow{4}{*}{$\begin{array}{l}\text { Step } 2 \\
\text { (1) }\end{array}$} & \multicolumn{2}{|c|}{ Step 3} & \multicolumn{2}{|c|}{ Step 4} \\
\hline & & & \multicolumn{2}{|c|}{ Model } & \multicolumn{2}{|c|}{ Model } \\
\hline & & & 1.1 & 1.2 & 1.1 & 1.2 \\
\hline & & & TEXF & HLEX & TEXF & HLEX \\
\hline Control Variables & & & & & & \\
\hline PPM & .059 & .058 & .067 & .071 & .064 & .071 \\
\hline ROE & $.105^{*}$ & $.105^{*}$ & $.108 *$ & $.128 * *$ & $.107 *$ & $.129 * *$ \\
\hline $\mathrm{CR}$ & -.021 & -.021 & -.030 & -.040 & -.023 & -.038 \\
\hline $\mathrm{DE}$ & .001 & .001 & .016 & .016 & .018 & .016 \\
\hline LNTA & $.486^{* *}$ & $.486^{* *}$ & $.428 * *$ & $.424 * *$ & $.424 * *$ & $.423^{* *}$ \\
\hline CONG & -.012 & -.012 & -.081 & -.077 & -.082 & -.077 \\
\hline BIG4 & $.112 *$ & $.113^{*}$ & .074 & .084 & .072 & .083 \\
\hline Independent Variable & & & & & & \\
\hline $\begin{array}{l}\text { ACFL } \\
\text { Moderating Variable }\end{array}$ & & .005 & .026 & .007 & -.020 & -.009 \\
\hline $\begin{array}{l}\text { MV } \\
\text { Interaction Terms }\end{array}$ & & & $-.305 * *$ & $-.255^{* *}$ & $-.392 * *$ & $-.282 * *$ \\
\hline $\begin{array}{l}\text { ACFL x MV } \\
\text { Statistics }\end{array}$ & & & & & .113 & .035 \\
\hline R Square & .325 & .325 & .408 & .381 & .411 & .381 \\
\hline Adjusted R Square & .310 & .307 & .390 & .363 & .391 & .361 \\
\hline R Square Change & .325 & .000 & .083 & .056 & .003 & .000 \\
\hline F Change & $21.243^{* *}$ & .013 & $42.940 * *$ & $27.675 * *$ & 1.460 & .138 \\
\hline Durbin-Watson & & & & & 1.756 & 1.783 \\
\hline Tolerance Min/Max & & & & & $.894 / .984$ & $.858 / .984$ \\
\hline Control Variables & & & & & & \\
\hline PPM & .059 & .053 & .062 & .066 & .062 & .066 \\
\hline ROE & $.105^{*}$ & $.103 *$ & $.106^{*}$ & $.125 * *$ & $.105^{*}$ & $.124 *$ \\
\hline $\mathrm{CR}$ & -.021 & -.024 & -.031 & -.041 & -.031 & -.040 \\
\hline $\mathrm{DE}$ & .001 & -.010 & .004 & .006 & .002 & .004 \\
\hline LNTA & $.486^{* * *}$ & $.488 * *$ & $.431 * *$ & $.428 * *$ & $.432 * *$ & $.429 * *$ \\
\hline CONG & -.012 & -.006 & -.076 & -.070 & -.073 & -.068 \\
\hline BIG4 & $.112^{*}$ & $.108^{*}$ & .068 & .081 & .068 & .080 \\
\hline Independent Variable & & & & & & \\
\hline $\begin{array}{l}\text { ACEX } \\
\text { Moderating Variable }\end{array}$ & & $.112 *$ & $.119 * *$ & $.094 *$ & $.139 *$ & $.119 *$ \\
\hline MV & & & $-.306 * *$ & $-.247 * *$ & $-.295 * *$ & $-.233 * *$ \\
\hline Interaction Terms & & & & & & \\
\hline ACEX x MV & & & & & -.033 & -.041 \\
\hline Statistics & & & & & & \\
\hline R Square & .325 & .337 & .421 & .389 & .422 & .390 \\
\hline Adjusted R Square & .310 & .320 & .404 & .371 & .403 & .370 \\
\hline R Square Change & .325 & .012 & .084 & .052 & .001 & .001 \\
\hline F Change & $21.243^{* *}$ & $5.766^{*}$ & $44.378 * *$ & $26.141 * *$ & .295 & .449 \\
\hline Durbin-Watson & & & & & 1.765 & 1.791 \\
\hline Tolerance Min/Max & & & & & $.894 / .993$ & $.858 / .987$ \\
\hline
\end{tabular}


(continued)

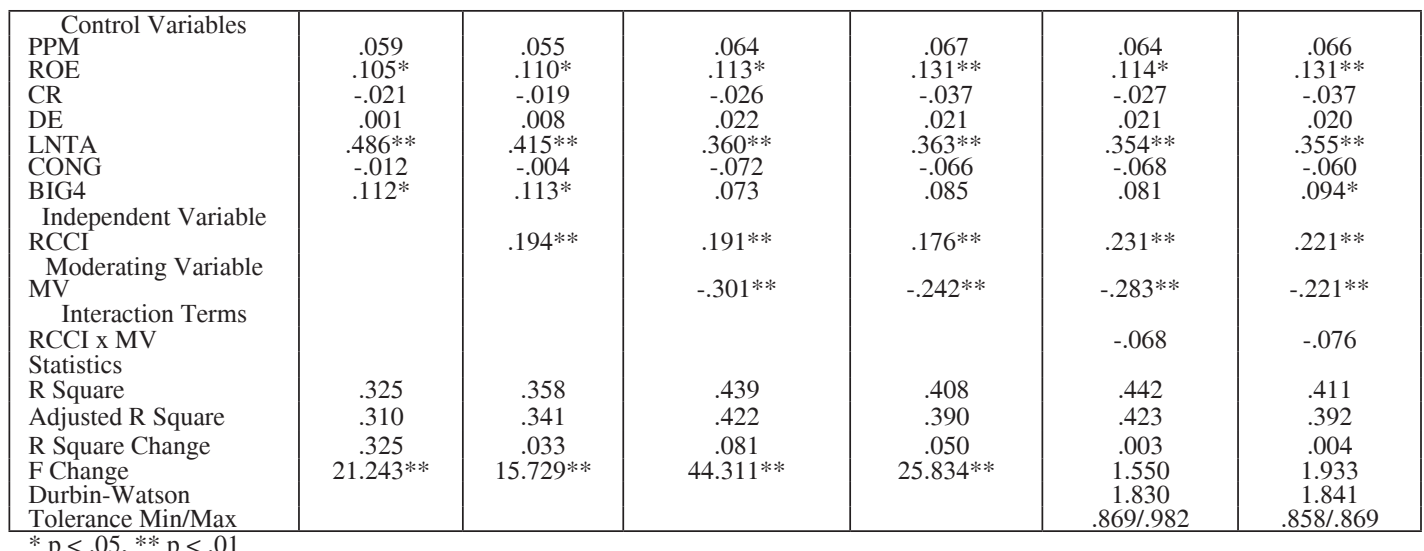

\section{(continued)}

\begin{tabular}{|c|c|c|c|c|c|c|}
\hline \multirow{4}{*}{ Variables } & \multicolumn{6}{|c|}{ Standardised Beta } \\
\hline & \multirow{3}{*}{$\begin{array}{c}\text { Step } 1 \\
\text { CV } \\
(1)-(7)\end{array}$} & \multirow{3}{*}{$\begin{array}{l}\text { Step } 2 \\
(1)\end{array}$} & \multirow{2}{*}{\multicolumn{2}{|c|}{$\frac{\text { Step } 3}{\text { Model }}$}} & \multicolumn{2}{|c|}{ Step 4} \\
\hline & & & & & & \\
\hline & & & 1.1 & 1.2 & 1.1 & 1.2 \\
\hline Control Variables & & & TEXF & HLEX & TEXF & HLEX \\
\hline PPM & .059 & .045 & .054 & .058 & .055 & .059 \\
\hline ROE & $.105^{*}$ & $.116^{*}$ & $.118^{*}$ & $.136^{* * *}$ & $.118 *$ & $.137 * *$ \\
\hline $\mathrm{CR}$ & -.021 & -.024 & -.030 & -.040 & -.031 & -.046 \\
\hline $\mathrm{DE}$ & .001 & -.007 & .007 & .007 & .006 & .001 \\
\hline LNTA & $.486 * *$ & $.399 * *$ & $.352 * *$ & $.352 * *$ & $.350 * *$ & $.342 * *$ \\
\hline CONG & -.012 & .005 & -.062 & -.056 & -.061 & -.047 \\
\hline $\begin{array}{l}\text { BIG4 } \\
\text { Independent Variable }\end{array}$ & $.112 *$ & $.104 *$ & .066 & .078 & .068 & .087 \\
\hline RCPR & & $.238 * *$ & $.220 * *$ & $.214 * *$ & $.238 * *$ & $.300 * *$ \\
\hline Moderating Variable & & & & & & \\
\hline $\begin{array}{l}\text { MV } \\
\text { Interaction Terms }\end{array}$ & & & $-.290 * *$ & $-.234 * *$ & $-.277 * *$ & $-.175 * *$ \\
\hline $\begin{array}{l}\text { RCPR x MV } \\
\text { Statistics }\end{array}$ & & & & & -.031 & $-.135^{*}$ \\
\hline R Square & .325 & .372 & .447 & .419 & .448 & .428 \\
\hline Adjusted R Square & .310 & .356 & .431 & .402 & .430 & .410 \\
\hline R Square Change & .325 & .047 & .075 & .046 & .001 & .010 \\
\hline F Change & $21.243 * *$ & $23.264 * *$ & $41.742 * *$ & $24.498 * *$ & 297 & $5.085^{*}$ \\
\hline Durbin-Watson & & & & & 1.873 & 1.892 \\
\hline Tolerance Min/Max & & & & & $.838 / .979$ & $.838 / .976$ \\
\hline Control Variables & & & & & & \\
\hline $\begin{array}{l}\text { PPM } \\
\text { ROE }\end{array}$ & $\begin{array}{l}.059 \\
105 *\end{array}$ & $\begin{array}{l}.025 \\
0.079 *\end{array}$ & $\begin{array}{l}.034 \\
083 *\end{array}$ & $\begin{array}{l}.037 \\
100 * *\end{array}$ & $\begin{array}{l}.040 \\
077 *\end{array}$ & .041 \\
\hline CR & -.021 & .025 & .018 & .008 & .012 & .010 \\
\hline DE & .001 & .010 & .023 & .022 & .016 & .014 \\
\hline LNTA & $.486 * *$ & $.185^{* * *}$ & $.132 * *$ & $.139 * *$ & $.129 * *$ & $.127 * *$ \\
\hline CONG & -.012 & .031 & -.037 & -.027 & -.033 & -.013 \\
\hline $\begin{array}{l}\text { BIG4 } \\
\text { Independent Variable }\end{array}$ & $.112^{*}$ & $.112 * *$ & $.073^{*}$ & $.086^{*}$ & $.079 *$ & $.098 * *$ \\
\hline BOQI & & $.602 * *$ & $.598 * *$ & $.588^{* * *}$ & $.684 * *$ & $.696^{* *}$ \\
\hline $\begin{array}{l}\text { Moderatıng Variable } \\
\text { MV }\end{array}$ & & & $-.296^{* *}$ & $-.223 * *$ & .088 & .248 \\
\hline Interaction Terms & & & & & 206** & $478 \% *$ \\
\hline $\begin{array}{l}\text { BOQI x MV } \\
\text { Statistics }\end{array}$ & & & & & $-.396^{* *}$ & $-.478 * *$ \\
\hline R Square & .325 & .584 & .662 & .626 & .671 & .639 \\
\hline Adjusted R Square & .310 & .573 & .652 & .615 & .660 & .628 \\
\hline R Square Change & .325 & .259 & 078 & .043 & .009 & .013 \\
\hline F Change & $21.243 * *$ & $191.405 * *$ & $71.039 * *$ & $35.028 * *$ & $8.541 * *$ & $11.044^{* *}$ \\
\hline Durbin-Watson & & & & & 1.952 & 1.846 \\
\hline Tolerance Min/Max & & & & & $.713 / .930$ & $.713 / .904$ \\
\hline
\end{tabular}

$* \mathrm{p}<.05, * * \mathrm{p}<.01$ 
Table 11 provides hierarchical regression results using control variables, independent variable, and moderating variables in model 1.1 and model 1.2 on the relationship between each dimensions of the board of directors' quality and the level of voluntary disclosure adjusted for items that are not applicable to the firm.

The results of the four-step hierarchical regression undertaken to test the hypotheses and seven control variables of this study are shown in Table 11. As seen in Table 11, when the seven firm characteristics as control variables were entered into the regression equation in the first step, the coefficient of determination $\left(\mathrm{R}^{2}\right)$ was found to be .325 , indicating that $32.5 \%$ of the level of voluntary disclosure is explained by the firm characteristics. It can be observed that control variables (ROE, LNTA, and BIG4) did have significant influence on VDI. ROE (Std. Beta $=.105)$ showed a significant and positive relationship with VDI at the .05 level. LNTA (Std. Beta $=.486$ ) showed a significant and positive relationship with VDI at the .01 level. BIG4 (Std. Beta $=.112$ ) showed a significant and positive relationship with VDI at the .05 level. These results provided support for $\mathrm{CV}(2), \mathrm{CV}(5)$, and $\mathrm{CV}(7)$ and not support for CV(1), CV(3), CV(4), and $\mathrm{CV}(6)$ of the study.

In step 2, by adding the 17 independent variables, namely BCEO, BCIN, BI51, BIAL, BMAL, BMA4, BIAD, ACCI, IDAC, ACIN, ACMA, ACA4, ACFL, ACEX, RCCI, RCPR, and BOQI have $\mathrm{R}^{2}$ increased to $34.3,34.5,34.9,36.5$, $32.5,32.5,34.0,34.1,35.8,35.1,33.5,33.0,32.5$, $33.7,35.8,37.2$, and $58.4 \%$, respectively, with $\mathrm{R}^{2}$ change (.018) is significant, (.020) is significant, (.024) is significant, (.040) is significant, (.000) is not significant, $(.000)$ is not significant, $(.015)$ is significant, (.016) is significant, (.033) is significant, (.027) is significant, (.010) is significant, (.006) is not significant, (.000) is not significant, (.012) is significant, (.033) is significant, (.047) is significant, and (.259) is significant, respectively. This implied that the additional $1.8 \%, 2.0 \%, 2.4 \%, 4.0 \%, 0.0 \%, 0.0 \%$, $1.5 \%, 1.6 \%, 3.3 \%, 2.7 \%, 1.0 \%, 0.6 \%, 0.0 \%$, $1.2 \%, 3.3 \%, 4.7 \%$, and $25.9 \%$ of the variation in VDI is explained by BCEO, BCIN, BI51, BIAL, BMAL, BMA4, BIAD, ACCI, IDAC, ACIN, ACMA, ACA4, ACFL, ACEX, RCCI, RCPR, and BOQI, respectively. As for the independent variables, namely, BCEO (Std. Beta $=.136)$, BCIN (Std. Beta $=.142)$, BI51 $($ Std. Beta $=.163)$, BIAL (Std. Beta $=.216)$, BIAD (Std. Beta $=$ $.125)$, ACCI (Std. Beta $=.129)$, IDAC (Std. Beta $=.187)$, ACIN (Std. Beta = .166), ACMA (Std. Beta $=.101)$, ACEX (Std. Beta $=.112)$, RCCI $($ Std. Beta $=.194)$, RCPR $($ Std. Beta $=.238)$, and BOQI (Std. Beta $=.602$ ) were found to have significant and positive relationships with VDI at the .05 level. These results provided support for the Hypotheses 1(1), 1(2), 1(3), 1(4), 1(7), 1(8), 1(9), 1(10), 1(11), 1(14), 1(15), 1(16), and 1(17) of the study, respectively, which indicated that 13 dimensions of the board of directors' quality have significant and positive relationships with the level of voluntary disclosure. However, the independent variables, namely, BMAL (Std. Beta $=.014)$, BMA4 (Std. Beta $=.003)$, ACA4 (Std. Beta $=.078)$, and ACFL (Std. Beta $=.005)$ were found to have no significant relationships with VDI at the .05 level. These results provided no support for the Hypotheses 1(5), 1(6), 1(12), and 1(13) of the study, respectively.

\section{Moderating Affects of an Executive Director that has a Family Member and Largest Shareholder Involved (TEXF)}

In the third step of model 1.1(1) - (17), TEXF was entered into the equation in order to gauge its impact as an independent predictor. The $\mathrm{R}^{2}$ increased from $34.3,34.5,34.9,36.5,32.5,32.5$, 34.0, 34.1, 35.8, 35.1, 33.5, 33.0, 32.5, 33.7, 35.8, 37.2 , and $58.4 \%$ to $41.2,42.0,44.2,44.6,40.9$, $40.7,41.5,42.9,44.6,44.2,41.2,41.7,40.8,42.1$, $43.9,44.7$, and $66.2 \%$ indicating a change of 7.0 , 7.5, 9.3, 8.2, 8.4, 8.2 , 7.5, 8.8, 8.8, 9.0, 7.7, 8.7, $8.3,8.4,8.1,7.5$, and $7.8 \%$, respectively meaning TEXF of all dimensions are significant $(p<.05)$.

In the fourth and final step of model 1.1(1) - (16), one interaction term of BCEO, BCIN, BI51, BIAL, BMAL, BMA4, BIAD, ACCI, IDAC, ACIN, ACMA, ACA4, ACFL, ACEX, RCCI, and RCPR, and TEXF were entered into model 1.1(1) - (16). From Table 11, it can be seen that the additional yield ( $\mathrm{F}$ change $=2.078)$, $(\mathrm{F}$ change $=.268),(\mathrm{F}$ change $=.421),(\mathrm{F}$ change $=.678),(\mathrm{F}$ change $=.636),(\mathrm{F}$ change $=.871),(\mathrm{F}$ change $=.015),(\mathrm{F}$ change $=1.134),(\mathrm{F}$ change $=$ $.001),(\mathrm{F}$ change $=.046),(\mathrm{F}$ change $=.072),(\mathrm{F}$ change $=.069),(\mathrm{F}$ change $=1.460),(\mathrm{F}$ change $=$ $.295),(\mathrm{F}$ change $=1.550)$, and $(\mathrm{F}$ change $=.297)$, 
and changes in the squared multiple correlation equal to .004 $\left(\Delta \mathrm{R}^{2}=.004\right), .001\left(\Delta \mathrm{R}^{2}=.001\right)$, $.001\left(\Delta \mathrm{R}^{2}=.001\right), .001\left(\Delta \mathrm{R}^{2}=.001\right), .001\left(\Delta \mathrm{R}^{2}=\right.$ $.001), .002\left(\Delta \mathrm{R}^{2}=.002\right), .000\left(\Delta \mathrm{R}^{2}=.000\right), .002$ $\left(\Delta \mathrm{R}^{2}=.002\right), .000\left(\Delta \mathrm{R}^{2}=.000\right), .000\left(\Delta \mathrm{R}^{2}=.000\right)$, $.000\left(\Delta \mathrm{R}^{2}=.000\right), .000\left(\Delta \mathrm{R}^{2}=.000\right), .003\left(\Delta \mathrm{R}^{2}=\right.$ $.003), .001\left(\Delta \mathrm{R}^{2}=.001\right), .003\left(\Delta \mathrm{R}^{2}=.003\right)$, and $.001\left(\Delta \mathrm{R}^{2}=.001\right)$, explained by the interaction terms $(0.4,0.1,0.1,0.1,0.1,0.2,0.0,0.2,0.0$, $0.0,0.0,0.0,0.3,0.1,0.3$, and $0.1 \%)$, respectively were not significant at the .05 level, indicating that there are no moderation effect. Thus, type of TEXF as moderator variable is Type 1 (an independent predictor variable). From the final regression equation, it was not observed that the interaction term (i.e. BCEO, BCIN, BI51, BIAL, BMAL, BMA4, BIAD, ACCI, IDAC, ACIN, ACMA, ACA4, ACFL, ACEX, RCCI, and RCPR $x$ TEXF) was not significant at the .05 level. The results derived from the final step did not provide support for Hypothesis 2.1(1) - (16) of the study, which indicates that the relationship between the BCEO, BCIN, BI51, BIAL, BMAL, BMA4,
BIAD, ACCI, IDAC, ACIN, ACMA, ACA4, ACFL, ACEX, RCCI, and RCPR and the level of voluntary disclosure (VDI) is not moderated by an executive director that has a family member and largest shareholder involved (TEXF).

In the fourth and final step of model 1.1(17), the one interaction term of BOQI was entered into the Model 1.1(17). From Table 11, it can be seen that the additional yield (F Change $=8.541, \mathrm{p}<.01)$ and changes in the squared multiple correlation equal $.009\left(\Delta \mathrm{R}^{2}=.009\right)$, explained by the interaction terms $(0.9 \%)$ that were significant at the .01 level, indicating that model 1.1(17) is a moderation effect. Thus, type of TEXF as a moderator variable is Type 3 (Quasi Moderator). From the final regression equation, it can be observed that one interaction term (BOQI x TEXF) was significant at the .01 level. The results derived from the final step provided support for Hypotheses 2.1(17) of the study.

The result of the significant interaction is presented in Figure 2.

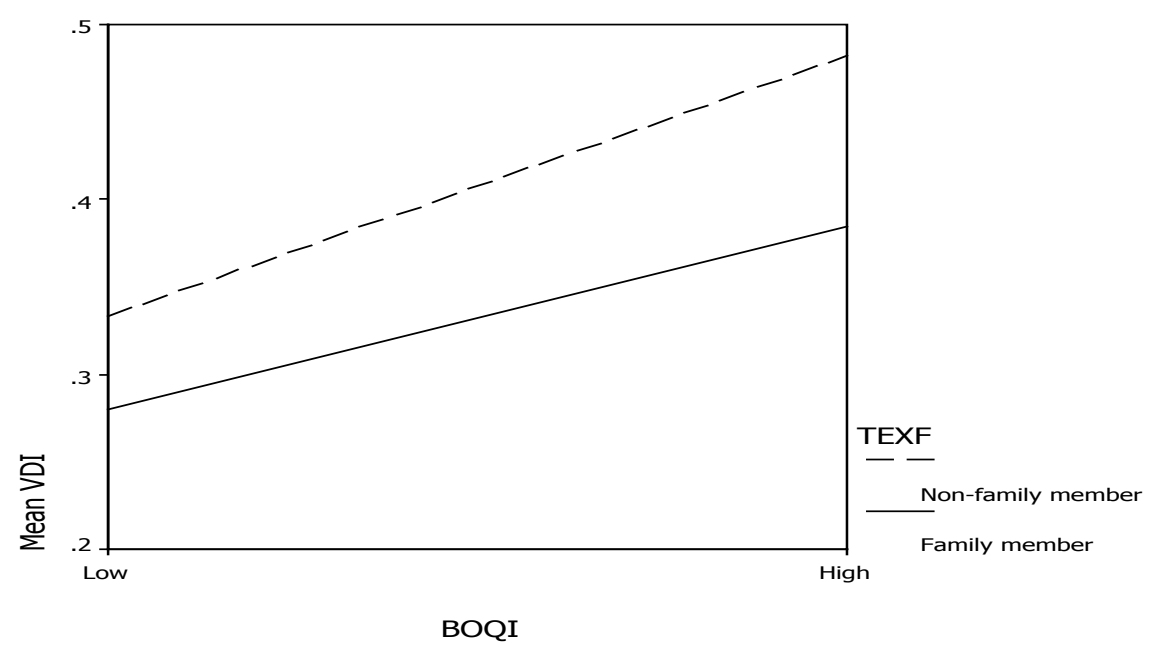

Figure 2: Interaction between the board of directors' quality index (BOQI) and an executive director that has the family member, largest shareholder involved (TEXF) for the level of voluntary disclosure (VDI) 
The interactions of BOQI and TEXF support had negatively significant (Std. Beta $=$ $-.396, p<.01$ ) effects on the study's dependent variable as the level of voluntary disclosure (VDI). Thus, hypothesis 2 is supported.

Plotting the interactions of BOQI and TEXF for VDI (Figure 2) shows that at low levels of BOQI there is a significant difference, with respondents with an executive director that has a family member and largest shareholder involved (family member) lower the level of voluntary disclosure (VDI), while those with an executive director that has no family member and largest shareholder involved (Non-Family member) report higher level of voluntary disclosure (VDI). This effect is further exacerbated (i.e. distance between an executive director that has the family member and non-family member, largest shareholder involved increased) when the boards of directors' quality index increase. At high levels of BOQI, the result showed to be the same as at low levels of BOQI, and reported increased gap of the level of voluntary disclosure (VDI).

\section{Moderating Effects of a High Concentration of Executive Directors' Ownership (HLEX)}

In the third step of model 1.2(1) - (17), HLEX were entered into the equation in order to gauge its impact as an independent predictor. The $\mathrm{R}^{2}$ increased from $34.3,34.5,34.9,36.5,32.5,32.5$, $34.0,34.1,35.8,35.1,33.5,33.0,32.5,33.7,35.8$, 37.2 , and $58.4 \%$ to $38.8,39.5,40.6,41.3,38.2$, $38.1,39.3,39.9,41.2,41.0,38.9,39.0,38.1,38.9$, $40.8,41.9$, and $62.6 \%$ indicating a change of 4.5 , 5.0, 5.8, 4.9, 5.7, 5.6, 5.4, 5.8, 5.5, 5.9, 5.4, 5.9, 5.6, 5.2, 5.0, 4.6, and $4.3 \%$, respectively meaning HLEX of all dimensions are significant $(p<.05)$.

In the fourth and final step of model 1.2(1) - (15), one interaction term of BCEO, BCIN, BI51, BIAL, BMAL, BMA4, BIAD, ACCI, IDAC, ACIN, ACMA, ACA4, ACFL, ACEX, and RCCI, and HLEX were entered into Model 1.2(1) - (15). From Table 11, it can be seen that the additional yield ( $\mathrm{F}$ change $=2.638$ ), $(\mathrm{F}$ change $=.666),(\mathrm{F}$ change $=.404),(\mathrm{F}$ change $=3.478),(\mathrm{F}$ change $=1.008),(\mathrm{F}$ change $=1.906)$,
$(\mathrm{F}$ change $=.000),(\mathrm{F}$ change $=1.526),(\mathrm{F}$ change $=3.564),(\mathrm{F}$ change $=.959),(\mathrm{F}$ change $=.086),(\mathrm{F}$ change $=.009),(\mathrm{F}$ change $=.138),(\mathrm{F}$ change $=$ $.449),(\mathrm{F}$ change $=1.933)$, and $(\mathrm{F}$ change $=.297)$, and changes in the squared multiple correlation equal to $.005\left(\Delta \mathrm{R}^{2}=.005\right), .001\left(\Delta \mathrm{R}^{2}=.001\right), .001$ $\left(\Delta \mathrm{R}^{2}=.001\right), .007\left(\Delta \mathrm{R}^{2}=.007\right), .002\left(\Delta \mathrm{R}^{2}=.002\right)$, $.004\left(\Delta \mathrm{R}^{2}=.004\right), .000\left(\Delta \mathrm{R}^{2}=.000\right), .003\left(\Delta \mathrm{R}^{2}=\right.$ $.003), .007\left(\Delta \mathrm{R}^{2}=.007\right), .002\left(\Delta \mathrm{R}^{2}=.002\right), .000$ $\left(\Delta \mathrm{R}^{2}=.000\right), .000\left(\Delta \mathrm{R}^{2}=.000\right), .000\left(\Delta \mathrm{R}^{2}=.000\right)$, $.001\left(\Delta \mathrm{R}^{2}=.001\right)$, and $.004\left(\Delta \mathrm{R}^{2}=.004\right)$ explained by the interaction terms $(0.5,0.1,0.1,0.7,0.2$, $0.4,0.0,0.3,0.7,0.2,0.0,0.0,0.0,0.1$, and $0.4 \%$ ), were not significant at the .05 level, indicating that there are no moderation effects, respectively. Thus, type of TEXF as a moderator variable is Type 1 (an independent predictor variable). From the final regression equation, it was not observed that the interaction term (i.e. BCEO, BCIN, BI51, BIAL, BMAL, BMA4, BIAD, ACCI, IDAC, ACIN, ACMA, ACA4, ACFL, ACEX, and RCCI $x$ HLEX) was not significant at the .05 level. The results derived from the final step did not provide support for Hypothesis 2.2(1) - (15) of the study which indicates that the relationship between the BCEO, BCIN, BI51, BIAL, BMAL, BMA4, BIAD, ACCI, IDAC, ACIN, ACMA, ACA4, ACFL, ACEX, and RCCI and the level of voluntary disclosure (VDI) is not moderated by a high concentration of executive directors' ownership (HLEX).

In the fourth and final step of model 1.2(16), the one interaction term of RCPR was entered into the Model 1.2(16). From Table 11, it can be seen that the additional yield (F Change $=5.085, \mathrm{p}<.05)$ and changes in the squared multiple correlation equal to $.010\left(\Delta \mathrm{R}^{2}=.010\right)$, explained by the interaction terms $(1.0 \%)$, was significant at the .05 level, indicating that Model 1.2(16) is a moderation effect. Thus, type of HLEX as a moderator variable is Type 3 (Quasi Moderator). From the final regression equation, it can be observed that one interaction term (RCPR x HLEX) was significant at the .05 level. The results derived from the final step provided support for the Hypotheses 2.2(16) of the study.

The result of the significant interaction is presented in Figure 3. 


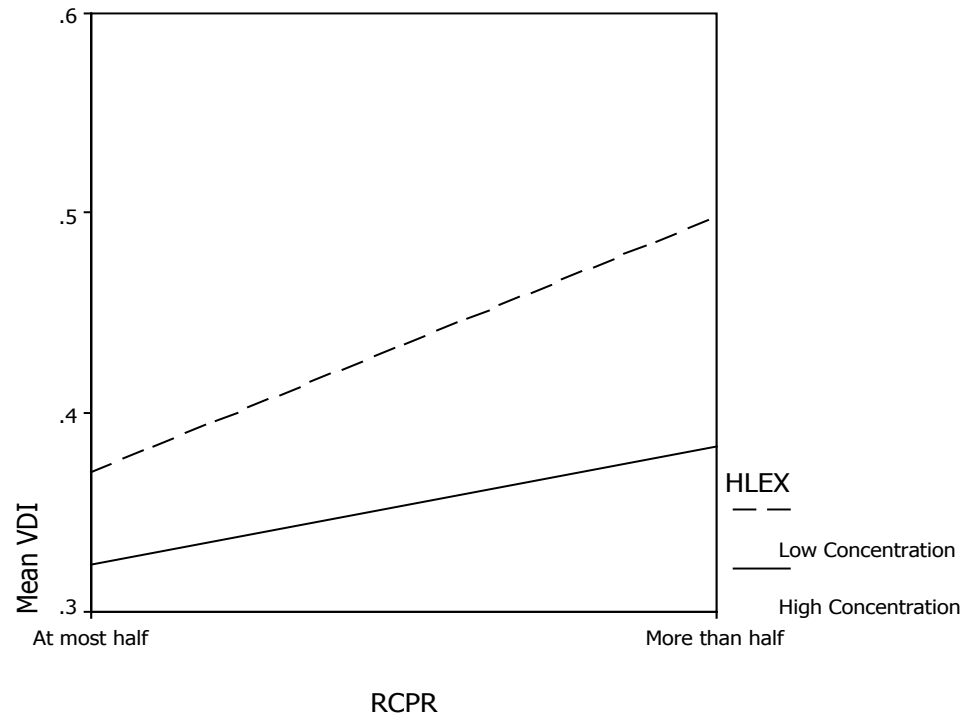

Figure 3: Interactions between more than half of the RC members are non-executive directors (RCPR) and a high concentration of executive directors' ownership (HLEX) for the level of voluntary disclosure (VDI).

Plotting the interactions of RCPR and HLEX for VDI (Figure 3) shows that at most half of the RC members are non-executive directors (At most half) level respondents with a high concentration of executive directors' ownership (High Concentration) reported lower level of voluntary disclosure (VDI), while those with a low concentration of executive directors' ownership (Low Concentration) reported higher level of voluntary disclosure (VDI). This effect is further exacerbated (i.e. distance between high and low concentration of executive directors' ownership increased) when the proportion of non-executive directors on remuneration committee increases. At more than half of the RC members being non-executive directors (More than half) level, the result showed that same as at most half of the $\mathrm{RC}$ members being non-executive directors and reported increased gap of the level of voluntary disclosure (VDI). The findings also supported the hypothesis that the existence of more than half of the RC members being non-executive directors will help enhance monitoring quality and reduce the advantages gained by withholding information, thereby improving voluntary disclosure in firm with a high and a low concentration of executive directors' ownership.

In the fourth and final step of model 1.2(17), the one interaction term of BOQI was entered into the Model 1.2(17). From Table 11, it can be seen that the additional yield (F Change $=11.044, \mathrm{p}<.01)$ and changes in the squared multiple correlation equal to $.013\left(\Delta \mathrm{R}^{2}=.013\right)$, explained by the interaction terms $(1.3 \%)$, was significant at the .05 level, indicating that model 1.2(17) is a moderation effect. Thus, type of HLEX as a moderator variable is Type 3 (Quasi Moderator). From the final regression equation, it can be observed that one interaction term (BOQI $x$ HLEX) was significant at the .05 level. The results derived from the final step provided support for the Hypotheses 2.2(17) of the study. 
The result of the significant interaction is presented in Figure 4.

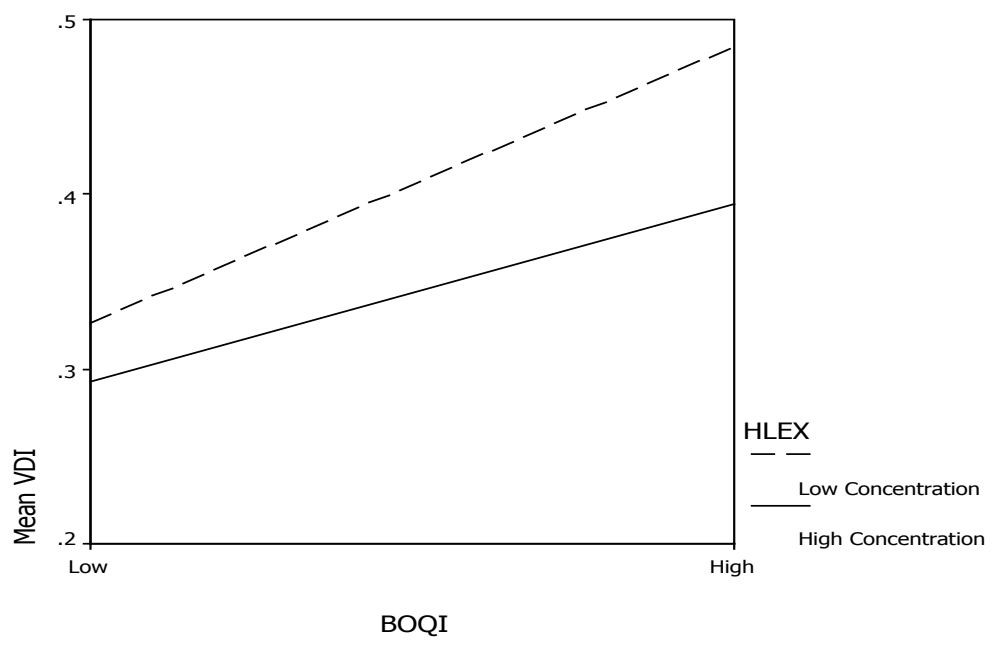

Figure 4: Interaction between the board of directors' quality index (BOQI) and a high concentration of executive directors' ownership (HLEX) for the level of voluntary disclosure (VDI)

The interactions of BOQI and HLEX support had negatively significant (Std. Beta $=$ $-.478, p<.01$ ) effects on the study's dependent variable, which was the level of voluntary disclosure (VDI). Thus, hypothesis 3 is supported. Plotting the interactions of BOQI, and HLEX for VDI (Figure 4) shows that at low levels of BOQI, there is a significant difference, with respondents with a high concentration of executive directors' ownership (High concentration) lower level of voluntary disclosure (VDI), while those with a low concentration of executive directors' ownership reported higher level of voluntary disclosure (VDI). This effect is further exacerbated (i.e. distance between high and low concentration of executive directors' ownership increased) when the boards of directors' quality index increase. At high levels of BOQI, the result showed to be the same as at low levels of BOQI and reported increased gap of the level of voluntary disclosure (VDI). The findings also supported the hypothesis that board of directors' quality can aid in enhancing voluntary disclosure in firms with a high and a low concentration of CEO's ownership.

\section{DISCUSSION}

\section{Level of the Board of Directors' Quality}

Judging on the level of the board of directors' quality in listed companies, this study was adapted from the assessment score of good governance among listed companies of Board of directors Centre of SET (SET, 2003) namely, equal or more than $80 \%$ of listed companies is very high, equal 70 but less than $80 \%$ of listed companies is high, equal 60 but less than $70 \%$ of listed companies is medium, equal 50 but less than $60 \%$ of listed companies is low, and less than $50 \%$ of listed companies is very low. The result of this study found that the level of board of director characteristics quality was $38.5 \%$ or very low.

This is because the quality of the board's leadership structure, the titles and authority of the board's chairman and head of management team are clearly separated, is low with $58.7 \%$ and the chairman of the board was an independent non-executive director (IND), is very low with $7.9 \%$ of the companies complying with that requirement. The quality of board's composition, 
more than $50 \%$ of the directors on the board were independent non-executive directors, is very low with only $3.2 \%$ and more than three directors of the board were INDs, is very low with $23.3 \%$ of the companies complying with that requirement. The quality of board's meetings, all directors were to attend every board meeting, is very low with only $5.7 \%$ and board's meetings more than 4 meetings a year, is high with $78.5 \%$ of companies comply with this requirement. The quality of board's controlling system and internal audit, the existence of internal audit department in the company, is high with $75.1 \%$ of the companies complying with this requirement. The quality of audit committee (AC)'s leadership structure, the existence of audit committee's chairman was an independent nonexecutive director, is very high with $89.3 \%$ of the companies complying with this requirement. The quality of the audit committee's composition, at least three audit committee members who were independent non-executive directors, is high with $73.2 \%$ and all members of AC were INDs, is high with $71.9 \%$ of companies complying with this requirement. The quality of audit committee's meetings, all audit committee members were to attend every audit committee meeting, is very low with $25.2 \%$ and $A C$ 's meetings more than 4 meetings a year, is low with $51.7 \%$ of companies complying with this requirement. The quality of audit committee's knowledge and expertise, all AC members have financial literacy, is very low with $2.8 \%$ and at least one audit committee member was a financial reporting expert such as $C P A$, is very low with $17 \%$ of companies complying with this requirement. The quality of remuneration committee's leadership, the existence of remuneration committee's chairman was an independent non-executive director, is also very low with $10.7 \%$ of companies complying with this requirement. The quality of the remuneration committee composition, more than half of the remuneration committee members were non-executive directors, is very low with $21.5 \%$ of companies complying with this requirement.

\section{Level of Voluntary Disclosure}

The judgment on the level of voluntary disclosure in listed companies in this study was adapted from Wallace (1988); because of the newness of this procedure, one cannot tell whether a particular percentage is poor, above average, etc., since there is no comparable data from any country. Statements on the level of voluntary disclosure in corporate annual reports are judgmental and guided by this general principle namely, voluntary disclosure index above $50 \%$ is considered high, between 30 and $50 \%$ is medium, and less than $30 \%$ is low.

This was because the mean of strategic information adjusted for items that are not applicable to the firm equals 0.48 , which is less than $50 \%$, is medium level; the mean of nonfinancial information adjusted for items that are not applicable to the firm equals to 0.28 , which is less than $30 \%$, is low level; the mean of financial information adjusted for items that are not applicable to the firm equals to 0.39 , which is less than $50 \%$, is medium level; and the mean of overall information adjusted for items that are not applicable to the firm equals 0.37 , which is less than $50 \%$, is medium level.

The possible reason for the mean of overall voluntary disclosure in 2004 was the medium level of Thailand's listed companies, that is, the voluntary disclosure provided reasonable assurance of accountability which reduces pressure of investors, lenders, regulators, and the public to the company for greater transparency. Consequently, Thai business leaders, board of directors, CEO, senior management, regulators, and professionals might speed up to fill in financial reports which is consistent with the proposed financial reports for investors and analysts consisting of categorise such as strategy, customers and markets, people and reputation, risk management, financial position, and financial performance. This would encourage more investments in the company because voluntary disclosure reduces the cost of capital (Lev, 1992); affects the cost of equity capital (Botosan, 1997); and cost of debt capital (Sengupta, 1998).

\section{The Relationship between the Board of Directors' Quality and the Level of Voluntary Disclosure Table 11 shows that each dimension of the board of directors' quality has significant and positive relationships with the level of voluntary disclosure. Hence, this suggests that when the board of directors' quality increases, it is}


more likely to have a higher level of voluntary disclosure. The results are consistent with Willekens et al. (2004) that they found firms with the existence of good corporate governance as the board of directors' quality report more on the voluntary disclosure of financial and non-financial performance information.

The findings supported the hypothesis that board of directors' quality can aid in enhancing voluntary disclosure and that voluntary disclosure is used as a means to reduce information asymmetry and agency problems.

Furthermore, it lends support to SET's principles of good corporate governance outlined to listed companies which they must begin implementing. Consequently, the implementation of these principles will bring great benefits to all listed companies as they demonstrate high standards of board of directors which help bring greater recognition to them both domestically and internationally. They will also promote transparency and managerial efficiency and therefore strengthen the confidence of all shareholders, investors, and other related parties.

\section{Moderating Effects of an Executive Director that} has a Family Member an, Largest Shareholder Involved

Contrary to expectation, the finding of this study showed that the impact of the quality of board's leadership structure, the quality of board's composition, the quality of board's controlling system and internal audit, the quality of audit committee's leadership structure, the quality of audit committee's composition, the quality of audit committee's knowledge and expertise, the quality of remuneration committee's leadership structure, and the quality of remuneration committee's composition on voluntary disclosure index (VDI) was not moderated by an executive director that has a family member, and largest shareholder involved (TEXF). Nevertheless, as can be seen from Table 11, it does not show the impact of the quality of board's meetings, the quality of audit committee's meetings, and the quality of audit committee's knowledge on the voluntary disclosure index, and there are no moderating effects of an executive director that has a family member and largest shareholder involved.

This finding is consistent with Dhnadirek and Tang (2003) that the relationship with financial reporting will not necessarily be the same between major shareholder ownership and managerial ownership. Furthermore, the role of managerial ownership with financial reporting quality is not clear, whether on average one would expect managerial ownership to increase or to reduce the quality of a firm's financial reporting (Han, 2005).

Thus, these results provide little guidance on how an executive director that has the family member, largest shareholder involved will have a negative impact on the relationship of the impact of the quality of board's leadership structure, the quality of board's composition, the quality of board's meetings, the quality of board's controlling system and internal audit, the quality of audit committee's leadership structure, the quality of audit committee's composition, the quality of audit committee's meetings, the quality of audit committee's knowledge and expertise, the quality of remuneration committee's leadership structure, the quality of remuneration committee's composition and the voluntary disclosure index.

However, the finding of this study showed that the impact of the level of board of director quality (BOQI) on the level of voluntary disclosure (VDI) is moderated by an executive director that has a family member involved $($ TEXF), $($ Std. Beta $=-.396, p<.01)$. Hence there is support for Hypotheses 2.1(17). This suggested that TEXF will negatively moderate the relationship between BOQI and VDI. These results are supported by Mok, Lam, and Cheung (1992), and Lam, Mok, Cheung and Yam (1994), and they argued that the appointment of independent nonexecutive directors in family controlled companies is likely to be influenced by the management's close relationship with prospective independent non-executive directors and the likelihood of their support for the management's philosophy and policies. Consequently, in the presence of family ownership and control, independent non-executive directors' independence may be compromised and their contribution to improve the management's responsiveness to investors might be reduced. Thus, these factors may reduce the independent non-executive directors' effectiveness in family owned and controlled companies. However, the problem of minority expropriation may arise when the ownership is concentrated in a specific group, 
particularly individual/family (Shleifer \& Vishny, 1997). Further, Hill (1999, p. 1127) argued that no one single mechanism is a governance panacea and suggested that it is desirable to have a system of overlapping checks and balances for the behaviours of controlling shareholders.

\section{Moderating Effects of a High Concentration of Executive Directors' Ownership}

Table 11 shows that a high concentration of executive directors' ownership will negatively moderate the relationship between the quality of remuneration committee's composition and the voluntary disclosure index. Hence, this finding is consistent with Bathala and Rao (1995) who found a negative relationship between board ownership and the proportion of outside directors on the board. Whidbee (1997) studied the relationship between determinants of the board composition in the US. He found that board composition reflects the ownership structure of the firm. In particular, he found that managers with high equity stakes use their voting rights to exclude outside directors from the board membership. Nevertheless, there are countervailing incentives for managers to reduce the quality of accounting information. The voting rights included in equity ownership make managers less subject to career concerns, the discipline of the product market, monitoring by outside shareholders, and value-enhancing takeovers (Gompers et al., 2003; Brown \& Caylor, 2006).

These results appear to be supported by Han (2005) who argued that the role of managerial ownership with financial reporting quality is not clear, whether on average one would expect managerial ownership to increase or to reduce the quality of a firm's financial reporting. Thus, these results provide little guidance on how a high concentration of executive directors' ownership (HLEX) will have a negative impact on the relationship of the quality of board's composition, the quality of board's meetings, the quality of board's controlling system and internal audit, the quality of audit committee's leadership structure, the quality of audit committee's composition, the quality of audit committee's meetings, the quality of audit committee's knowledge and expertise, the quality of remuneration committee's leadership structure, and the voluntary disclosure index.

Furthermore, the finding of this study showed that the impact of the level of board of director quality (BOQI) on the level of voluntary disclosure (VDI) is moderated by a high concentration of executive directors' ownership that has family members involved (HEXF), (Std. Beta $=-.478, p<.01)$. Hence there is support for Hypotheses 2.2(17). This suggested that HEXF will negatively moderate the relationship between BOQI and VDI. These results are support by Craswell and Taylor (1992), Haniffa and Cooke (2002), Hossain et al. (1994), Leftwich et al. (1981), McKinnon and Dalimunthe (1993), Naser (1998), and Raffournier (1995), where they argued that diffusion and types of equity owners have been suggested as important variables in explaining disclosure variability. Disclosure will be greater in companies with diffused ownership because it helps owners to monitor the behaviour of management as predicted by agency theory and the problem of minority expropriation may arise when the ownership is concentrated in a specific group, particularly individual/family (Shleifer \& Vishny, 1997). The findings also support suggested by Hill (1999) that no one single mechanism is a governance panacea and it is desirable to have a system of overlapping checks and balances for the behaviours of controlling shareholders for companies with a high concentration of executive directors' ownership.

\section{Impact of Control Variables on the Level of Voluntary Disclosure}

As can be seen from Table 11, it was found that, similar to the results reported by Chen and Jaggi (2000), the control variables of profit margin (PPM - CV(1)), liquidity ratio (CR - CV(3)), and debt-equity ratio (DE - CV(4)) were not statistically significant, and the control variables of earnings return (ROE - CV(2)), firm size as total assets (LNTA - CV(5)), and audit firm size influence (BIG4 - CV(7)) were statistically significant. The control variable of scope of business operations (CONG - CV(6)) was not found to be significant and this is not in line with Chen and Jaggi is (2000) findings. 
Earnings return, firm size, and auditor size influence, as expected were positively and significantly associated with disclosure levels. Given that the sample was made up of 317 nonfinancial listed companies in Thailand, these higher earnings return, higher total assets, and the existence of big audit firm size tend to exhibit higher disclosures. This might indicate that increased level of voluntary disclosure is driven by increased earnings return, total assets, and having the big audit firm as auditor.

Thus, these results indicated that firm characteristic (i.e. structure-related characteristics) which can be associated with agency theory, information and political costs, proprietary costs, and capital need measured by firm size, would be a positive control variable in hierarchical regression analysis to examine the effect of the quality of board of directors and ownership structure of the firm's corporate governance structure on the level of voluntary disclosure. This finding is consistent with Chen and Jaggi (2000), Cooke (1989b), Haniffa and Cooke (2002), and Hossain et al. (1995).

Furthermore, these results indicated that firm characteristic (i.e. performance-related characteristics), which is associated with support continuance and compensation measured by rate of return, would be a positive control variable in hierarchical regression analysis to examine the effect of the quality of board of directors and ownership structure of the firm's corporate governance structure on the level of voluntary disclosure. This finding is consistent with Chen and Jaggi (2000) and Singhvi and Desai (1971).

Finally, these results indicated that firm characteristic (i.e. market-related characteristics), which is associated with reputation costs and signaling agency costs measured by audit firm size influence, would be a positive control variable in hierarchical regression analysis to examine the effect of the quality of board of directors and ownership structure of the firm's corporate governance structure on the level of voluntary disclosure. This finding is consistent with Chen and Jaggi (2000) and Singhvi and Desai (1971).

\section{SUMMARY AND CONCLUSIONS}

\section{Summary}

Hypotheses 1(1), 1(2), 1(3), 1(4), 1(7), 1(8), 1(9), 1(10), 1(11), 1(14), 1(15), 1(16), and 1(17) were supported thus there is a positive significant relationship between each dimensions of board of director quality and the level of voluntary disclosure of companies listed on the SET. Hypothesis 2.1(17) was supported, thus an executive director that has a family member and largest shareholder involved will negatively moderate the relationship between the level of the board of directors' quality and the level of voluntary disclosure of companies listed on SET. Hypotheses 2.2(16) and 2.2(17) were supported, thus a high concentration of executive directors' ownership will negatively moderate the relationship between the quality of remuneration committee's composition, the level of the board of directors' quality, and the level of voluntary disclosure of companies listed on SET.

Similar to the results reported by Chen and Jaggi (2000), the control variables of profit margin (PPM), liquidity ratio (CR), debt-equity ratio (DE) were not statistically significant, and the control variables of natural logarithm of total assets (LNTA), auditor size influence (BIG4), and earnings return (ROE) were statistically significant. While the control variable of Scope of business operations (CONG) was significant in Chen and Jaggi (2000), it was not significant in this study.

\section{Limitations of the Study and Future Research}

There are a number of limitations of this study. One limitation is that the subjectivity problem inherent in scoring financial reports of a sample of companies may not be completely eliminated. Although every effort was made to produce an objective measure of firm's voluntary disclosure, as measured on 70 items (16 strategic information items, 27 non-financial information items, and 27 financial information items), it is possible that measurement errors still exist. Another limitation of this study was that no weights were attached to the items of voluntary disclosure. It was based on the maximum voluntary disclosure possible score and therefore the voluntary disclosure index for 
a company then becomes total disclosure score over maximum voluntary disclosure possible score. As in previous studies, the study was cross-sectional in nature and this may bias the results given that disclosure changes over time. Furthermore, this study was conducted on nonfinancial listed companies on the Stock Exchange of Thailand only, so the findings of this study might not be generalised to other sectors, cultures, or countries. The last limitation of this study was that it examined the level of voluntary disclosure in only one year. One year of data was considered and if other years were studied, the results may differ across different years.

\section{CONCLUSION}

The proposed framework was substantially validated. Jensen and Meckling's (1976) positive agency theory was supported. Overall in total squared multiple correlation of the level of voluntary disclosure $(67.1 \%)$ was explained by firm characteristics $(32.5 \%)$, the board of directors' quality index (25.9\%), moderating variable $(7.8 \%)$, and interaction terms $(0.9 \%)$.

The study highlights were the overall contribution on the whole body of research in positive agency theory. The study contributed to practice in voluntary disclosure checklist for the extent of level of voluntary disclosure in nonfinancial listed companies on the Stock Exchange of Thailand, which was measured by the voluntary disclosure index. Each company was measured by an index which is the proportion of the total score of voluntary disclosure awarded to a company to the score. The company could at most be expected to disclose with a maximum score of 70 . This provides a useful benchmark for comparison with other countries or economies with similar institutional backgrounds.

These results have a significant contribution to the agency theory since there is evidence to show that the relationship between the level of board of directors' quality, and each dimension of the board of directors' quality, and voluntary disclosure will not necessarily be the same between an executive director that has the family member and largest shareholder involved (negatively moderate), and an executive director that has no the family member and largest shareholder involved (positively moderate), and between a high concentration of executive directors' ownership (negatively moderate), and a low concentration of executive directors' ownership (positively moderate). Thus, these results suggested, that the nature of the agency problem has shifted away from managershareholder conflicts to type of controlling ownership conflicts between the family member and the non-family member, and concentration of controlling ownership conflicts between a high concentration and a low concentration of controlling ownership.

This study does not demonstrate that any single mechanism, such as executive directors with low ownership positions, is a governance cure-all. Therefore, it is hard to attain in the real world since listed companies in Thailand is highly concentrated and most of the shares are owned by executive directors. This study suggested that good corporate governance mechanisms as the board of directors' quality can assist with increasing the voluntary disclosure and that it is used as a means to decrease information asymmetry between major shareholders and minor shareholders. Thus, it is a system of block and balance of power of executive directors with family member and largest shareholder, and high ownership positions.

Finally, this study suggested that used firm-specific characteristics (i.e. structure-related characteristics such as firm size; performancerelated characteristics such as earnings return; and market-related characteristics such as audit size influence) as control variables include the model to study of the relationship between ownership structure, dimensions of corporate governance mechanisms (i.e. board of directors), and voluntary disclosure. 
Appendix 1: Voluntary Disclosure Checklist

\section{A. Strategic Information}

(1) General corporate information

V1 Brief history of company

V2 Organisational structure

(2) Corporate strategy

\section{V3 Statement of strategy and objectives - general}

V4 Statement of strategy and objectives - financial

V5 Statement of strategy and objectives - marketing

V6 Statement of strategy and objectives - social

V7 Impact of strategy on current results

V8 Impact of strategy on future results

(3) Research and development (R\&D)

V9 Corporate policy on R\&D

V10 Location of R\&D activities

V11 Number employed in R\&D

(4) Future prospects

V12 Statement of future prospects - qualitative

V13 Qualitative forecast of sales

V14 Qualitative forecast of profits

V15 Qualitative forecast of cash flows

V16 Order book or backlog information

B. Non-financial Information

(5) Employee information

V17 Geographical distribution of employees

V18 Line-of-business distribution of employees

V19 Categories of employees by gender

V20 Categories of employees by function

V21 Identification of senior management and their functions

V22 Number of employees for two or more years

V23 Reasons for changes in employee numbers or categories over time

V24 Amount spent in training

V25 Nature of training

V26 Policy on training

V27 Categories of employees trained

V28 Number of employees trained

V29 Safety policy

V30 Data on accidents

V31 Cost of safety measures

V32 Policy on communication

V33 Redundancy information

V34 Equal opportunity policy statement

V35 Recruitment problems and related policy

\section{B. Non-financial Information (Continued)}

(6) Social policy and value-added information

V36 Safety of products

V37 Environmental protection programmes - qualitative

V38 Environmental protection programmes - quantitative

V39 Community programmes

V40 Value-added statement

V41 Value-added data

V42 Value-added ratios

V43 Qualitative value-added information

C. Financial Information

(7) Segmental information

V44 Geographical production - quantitative

V45 Line-of-business production - quantitative

V46 Competitor analysis - qualitative

V47 Competitor analysis - quantitative

V48 Market share analysis - qualitative

V49 Market share analysis - quantitative

(8) Financial review

V50 Profitability ratios

V51 Qualitative comments on profitability

V52 Cash flow statement - direct

V53 Cash flow ratios

V54 Liquidity ratios

V55 Gearing ratios

V56 Disclosure of brand valuation

V57 Financial history or summary - six or more years

V58 Off balance sheet financial information

V59 Advertising information - qualitative

V60 Effects of inflation on future operations - qualitative

V61 Effects of inflation on results - qualitative

V62 Effects of inflation on assets - qualitative

V63 Effects of interest rates on results

V64 Effects of interest rates on future operations

(9) Foreign currency information

V65 Effects of foreign currency fluctuations on future operations
- qualitative

(10)

V67 Foreign currency exposure management description
V68 Share price trend
V69 Market capitalisation trend
V70 Foreign stock market listing information

\section{REFERENCES}

Abbott, L.J., \& Parker, S. (2000). Audit selection and audit committee characteristics. Auditing: A Journal of Practice and Theory, 19(2), 47-66.
Balachandran, J., \& Bliss, M. (2004). Board independence and voluntary disclosure: Evidence from Malaysia. Working Paper, Department of Accountancy City University of Hong Kong. 
Ball, R., Robin, A., \& Wu, J.S. (2003). Incentives versus standards: Properties of accounting income in four East Asian countries, and implications for acceptance of IAS. Journal of Accounting and Economics, 36(1-3), 235-270.

Bathala, C.T., \& Rao, R.P. (1995). The determinants of board composition: An agency perspective. Managerial and Decision Economics, 16, 59-69.

Beatty, R.P.,\& Zajac, E.J. (1994). Managerial incentives, monitoring, and riskbearing: A study of Executive compensation, ownership and board structure in initial public offerings. Administrative Science Quarterly, 39, 313-335.

Berg, S.V., \& Smith, S.K. (1978). CEO and board chairman: A quantitative study of dual VS unity board leadership. Directors and Boards, 3, 34-39.

Berle, A.A., \& Means, G.C., Jr. (1932). The modern corporation and private property. New York: Macmillan.

Botosan, C.A. (1997). Disclosure level and the cost of equity capital. The Accounting Review, 72(3), 323-349.

Brown, L.D., \& Caylor, M.L. (2006). Corporate governance and firm valuation. Journal of Accounting \& Public Policy, 25(4), 409-434.

Cadbury Report. (1992). Report of the committee on the Financial aspects of corporate governance. London: Gee Publishing.

Chau, G.K., \& Gray, S.J. (2002). Ownership structure and corporate voluntary disclosure in Hong Kong and Singapore. The International Journal of Accounting, 37, 247-265.

Chen, C.J.P., \& Jaggi, B. (2000). The association between independent non- executive directors, family control and financial disclosures. Journal of Accounting and Public Policy, 19(4-5), 285-310.
CIFAR (Center for International Financial Analysis \& Research). (1995). International accounting and auditing trends $4^{\text {th }}$ edi. Princeton, NJ: CIFAR Publications.

Cohen, J., \& Cohen, P. (1975). Applied multiple regression/correlation analysis for the behavioural sciences. Hillsdale, New Jersey: Lawrence Erlbaum Associates.

Conger, J.A., Finegold, D., \& Lawler, E. III (1998). Appraising boardroom performance. Harvard Business Review, 76(1), 136-148.

Cooke, T.E. (1989a). Voluntary corporate disclosure by Swedish companies. Journal of International Financial Management and Accounting, 1(2), Summer, 171-195.

Cooke, T.E. (1989b). Disclosure in the corporate annual reports of Swedish companies. Accounting and Business Research, 19(74), 113-124.

Craswell, A.T., \& Taylor, S.L. (1992). Discretionary disclosure of reserves by oil and gas companies: An economic analysis. Journal of Business Finance and Accounting, 19(2), January, 295308.

Cronbach, L.J. (1951). Coefficient alpha and the internal structure of tests. Psychometrika, 16(3), 297-334.

Darrough, M.N., \& Stoughton, N.M. (1990). Financial disclosure policy in an entry game. Journal of Accounting and Economics, 12, 219-243.

DeAngelo, L.E. (1981). Auditor size and audit quality. Journal of Accounting and Economics, 3(3), 183-199.

Dhnadirek, R., \& Tang, J. (2003). Corporate governance problems in Thailand: Is ownership concentration the cause? Asia Pacific Business Review, 10(2), 121-138. 
Diacon, S., \& O' Sullivan, N. (1996). Does corporate governance influence performance? Some evidence from UK insurance companies. International Review of Law and Economics, 15, 405-424.

Donaldson, L., \& Davis, J.H. (1991). Stewardship theory or agency theory: CEO governance and shareholder returns. Australian Journal of Management, 16(1), 49-65.

Dye, R.A. (1985). Strategic accounting choice and the effects of alternative financial reporting requirements. Journal of Accounting Research, 23(2), 544-574.

Dye, R.A. (1986). Proprietary and nonproprietary disclosures. Journal of Business, 59, 331-366.

Endo, T., Griffiths, M., Haksar, V., Schwartz, S., Barnett, S., \& Lee, I.H. (2000). Thailand: Selected issue. IMF Staff Country Report, 00/21, Feb.

Eng, L.L., \& Mak, Y.T. (2003). Corporate governance and voluntary disclosure. Journal of Accounting and Public Policy, 22, 325-345.

Evans, M. (2004). Board characteristics, firm ownership and voluntary disclosure. Working Paper, Fuqua School of Business, Duke University, Durham, NC. 27708, October.

Fama, E.F. (1980). Agency problems and theory of the firm. Journal of Political Economy, 88(2), 288-307.

Fama, E.F., \& Jensen, M.C. (1983a). Separation of ownership and control. The Journal of Law and Economics, 26(2), 301325.

Fama, E.F., \& Jensen, M.C. (1983b). Agency problems and residual claims. The Journal of Law and Economics, 26(2), 327-349.
Fan, J.P.H., \& Wong, T.J. (2002). Corporate ownership structure and the informativeness of accounting earnings in East Asia. Journal of Accounting and Economics, 33(3), 401-425.

Felo, A.J., Krisnamurthy, S., \& Solieri, S.A. (2003). Audit committee characteristics and the perceived quality of financial reporting :An empirical analysis. Working Paper Series, Binghamton University School of Management, from http://papers.ssrn.com.

Field, A. (2000). Discovering Statistic Using SPSS for Windows. London: Sage.

Forker, J.J. (1992). Corporate governance and disclosure quality. Accounting and Business Research, 22(86), 111-124.

Gompers, P., Ishii, J., \& Metrick, A. (2003). Incentives vs. control: An analysis of U.S. dual-class companies. NBER Working Paper Series, No. 10240.

Gray, S.J. (1988). Towards a theory of cultural influence on the development of accounting systems internationally. Abacus, 24(1), March, 1-15.

Gul, F.A., \& Leung, S. (2004). Board leadership, outside directors' expertise and voluntary corporate disclosures. Journal of Accounting and Public Policy, 23, 351-379.

Hair, J.F., Anderson, R.E., Tatham, R.L., \& Black, W.C. (1998). Multivariate data analysis. (5 ${ }^{\text {th }}$ ed.) New Jersey: Prentice Hall, Inc.

Han, S. (2005). Ownership structure and quality of financial reporting. Working Paper, Department of Accountancy, University of Illinois at UrbanaChampaign, February.

Haniffa, R.M., \& Cooke, T.E. (2002). Culture, corporate governance and disclosure in Malaysian corporations. ABACUS, 38(3), 317-349. 
Hayes, R., \& Lundholm, R. (1996). Segment reporting to the capital market in the presence of a competitor. Journal of Accounting Research, 34, 261-279.

Hill, J.G. (1999). Deconstructing sunbeamcontemporary issues in corporate governance. University of Cincinnati Law Review, 67, 1099-1127.

Ho, S.S.M., \& Wong, K.S. (2001). A study of the relationship between corporate governance structures and the extent of voluntary disclosure. Journal of International Accounting, Auditing and Taxation, 10, 139-156.

Hope, O.K. (2003). Analyst following and influence of disclosure components, IPOs and ownership concentration. Asia-Pacific Journal of Accounting and Economics, 10(2), 117-141.

Hossain, M., Perera, M.H.B., \& Rahman, A.R. (1995). Voluntary disclosure in the annual reports of New Zealand companies. Journal of International Financial Management and Accounting, 6(1), 69-87.

Hossain, M., Tan, L.M., \& Adams, M. (1994). Voluntary disclosure in an emerging capital market: Some empirical evidence from companies listed on the Kuala Lumpur Stock Exchange. The International Journal of Accounting, 29(4), 334-351.

Huafang, X., \& Jianguo, Y. (2007). Ownership structure, board composition and corporate voluntary disclosure: Evidence from listed companies in China. Managerial Auditing Journal, 22(6), 604-619.

IFC (International Finance Corporation). (1994). Emerging stock markets factbook 1994. Washington, D.C.: IFC.

Jensen, M.C. (1993). The modern industrial revolution, exit, and the failure of internal control systems. The Journal of Finance, 76, 323-329.
Jensen, M.C., \& Meckling, W.H. (1976). Theory of the firm: Managerial behavior, agency costs and ownership structure. Journal of Financial Economics, 3, October, 305-360.

Karamanou, I., \& Vafeas, N. (2005). The association between corporate boards, audit committees, and management earnings forecasts: An empirical analysis. Journal of Accounting Research, 43(3), 453-486.

Klein, A. (2002). Audit committee, board of director characteristics, and earnings management. Journal of Accounting and Economics, 33, 375-400.

Lam, K., Mok, H.M.K., Cheung, I., \& Yam, H.C.S. (1994). Family groupings on performance of portfolio selection in the Hong Kong stock market. Journal of Banking and Finance, 18(4), 725742.

Leftwich, R.W., Watts, R.L., \& Zimmerman, J.L. (1981). Voluntary corporate disclosure: The case of interim reporting. Journal of Accounting Research, 19, Supplement, 50-77.

Lev, B. (1992). Information disclosure strategy. California Management Review, 34, Summer, 9-32.

Leventis, S.N., \& Weetman, P. (2000). Exploring and explaining variations in voluntary disclosure in a European emerging capital market: Evidence from the Athens Stock Exchange. Paper submitted to the BAA [S] 2000 Regional conference University of Aberdeen.

Levitt, A. (2000). Renewing the covenant with investors. Speech at New York University Center for Law and Business. Retrieved January 20, 2008, from http:// www.sec.gov/news/speeches/spch370. htm

Limpaphayom, P. (2000). Corporate governance in Thailand before the crisis: Issues and implications. Accountants' Journal, 47(1), 10-20. 
Liouville, J., \& Bayad, M. (1998). Human resource management and performances: Proposition and test of a casual model. Human Systems Management, 17(3), 183-193.

Lipton, M., \& Lorsch, J.W. (1992). A modest proposal for improved corporate governance. The Business Lawyer, 48(1), 59-77.

Liu, C. (2004). The influence of audit committee oversight on corporate disclosure. Working Paper, Department of Accounting and Law, School of Management, State University of New York at Buffalo, January 19.

Luo, S., Courtenay, S.M., \& Hossain, M. (2006). The effect of voluntary disclosure, ownership structure and proprietary cost on the return-future earnings relation. Pacific-Basin Finance Journal, 14, 501-521.

Mak, Y.T., \& Li, Y. (2001). Determinants of corporate ownership and board structure: Evidence from Singapore. Journal of Corporate Finance, 7, 235256.

Mak, Y.T., \& Roush, M.L. (2000). Factors affecting the characteristics of boards of directors: An empirical study of New Zealand initial public offering firms. Journal of Business Research, 47, 147-159.

Manager Information Services. (1996). Listed companies hand book. Bangkok: Eastern Printing.

Mangena, M., \& Pike, R. (2005). The effect of audit committee shareholding, financial expertise and size on Interim financial disclosures. Accounting and Business Research, 35(4), 327-349.

McClelland, P., \& Barker, V.L. III (2004). The interaction of CEO age and ownership control in publicly traded firms: Performance implications. Working paper, School of Business, University of Kansas. Retrieved June 20, 2008, from http://people.ku.edu/ pmcc11/ Agexown.pdf
McKinnon, J.L., \& Dalimunthe, L. (1993). Voluntary disclosure of segment information by Australian diversified companies. Accounting and Finance, 33(1), May, 33-50.

McMullen, D.A., \& Raghunandan, K. (1996). Enhancing audit committee effectiveness. Journal of Accountancy, August, 79-81.

Meek, G.K., Roberts, C.B., \& Gray, S. (1995). Factors influencing voluntary annual report disclosures by US, UK and continental European multinational corporations. Journal of International Business Studies, 26(3), 555-572.

Mohd-Nasir, N., \& Abdullah, S.N. (2005). Voluntary disclosure and corporate governance among financially distressed firms in Malaysia. Working Paper, Monash University Malaysia and Universiti Utara Malaysia.

Mok, H.M.K., Lam, K., \& Cheung, I. (1992). Family control and return covariation in Hong Kong's common stocks. Journal of Business Finance and Accounting, 19(2), 277-293.

Naser, K. (1998). Comprehensiveness of disclosure of non-financial companies listed on the Amman Financial Market. International Journal of Commerce and Management, 8(1), 88-119.

Nielsen, S., Peck, S.I., \& Ruigrok, W. (2008). Substitution effects of internal governance mechanisms: Evidence from Switzerland. Corporate Ownership and Control, 5(3), 212-219.

Nikomborirak, D. (2001). An assessment of the role of board of directors in building good governance: The case of Thailand. TDRI Quarterly Review, 16(3), 14-21.

Nunnally, J.C., \& Bernstein, I.H. (1994). Psychometric theory (3rd ed.). New York: McGraw-Hill, Inc.

Pincus, K., Rusbarsky, M., \& Wong, J. (1989). Voluntary information of audit committees among NASDAQ firms. Journal of Accounting and Public Policy, 8(4), 239-265. 
Pipatseritham, K. (1981). The analysis of the ownership structure of Thai conglomerates. Thammasat University Press.

Pound, J. (1995). The promise of the governed corporation. Harvard Business Review, 73(2), 89-98.

Prasith-rathsint, S. (2005). Technique of multiple variables analysis in the social sciences and Behavioral research (5th. ed.). Bangkok: Samrada.

Priebjrivat, A. (1992). Corporate disclosure: A case of Securities Exchange of Thailand. Unpublished Doctoral Dissertation, New York University, School of Business Administration. University Microfilms International, Order No. 9220538.

Public Company Act. (1992). The public company act B.E. 2535. Retrieved June 18, 2008, from http://www. thairegistration.com/thai/law/public_ 01.pdf, 1-44

Raffournier, B. (1995). The determinants of voluntary financial disclosure by Swiss listed companies. The European Accounting Review, 4(2), 261-280.

Rechner, P.L., \& Dalton, D.R. (1991). CEO duality and organisational performance: A longitudinal analysis. Strategic Management Journal, 12(2), 155160.

Rezaee, Z. (2003). High-quality financial reporting. Strategic Finance, 84(8), Feb, 26-30.

Rosenstein, S., \& Wyatt, J.G. (1990). Outside directors, board independence, and shareholder wealth. Journal of Financial Economics, 26(2), 175-192.

Saudagaran, S.M., \& Diga, J.G. (1997). Financial reporting in emerging capital markets: Characteristics and policy issues. Accounting Horizons, 11(2), June, 41-64.

Scarbrough, P., Rama, D., \& Raghunandan, K. (1998). Audit committee composition and interaction with internal auditing: Canadian evidence. Accounting Horizons, March, 51-62.
Sengupta, P. (1998). Corporate disclosure and the cost of debt. The Accounting Review, 73(4), 459-474.

Sharma, S., Durand, R.M., \& Gur-Arie, O. (1981). Identification and analysis of moderator variables. Journal of Marketing Research, XVIII, August, 291-300.

Shleifer, A., \& Vishny, R.W. (1997). A survey of corporate governance. Journal of Finance, 52, 737-783.

Singhvi, S.S., \& Desai, H.B. (1971). An empirical analysis of the quality of corporate financial disclosure. The Accounting Review, 46(1), January, 129-138.

Spangler, W.D., \& Braiotta,L. (1990).Leadership and corporate audit effectiveness. Group and Organisational Studies, 15(2), 134-157.

Standard \& Poor's and the National University of Singapore (S\&P \& CGFRC). (2004). Corporate governance in Thailand: A study of SET 50 companies. Bangkok Post, Business, Wednesday, April 21, 1.

Stock Exchange of Thailand (SET). (1999). Best practice guidelines for the audit committee. Bangkok: Boonsiri Printing.

SET. (2001a). The 15 principles of good corporate governance. Bangkok: Boonsiri Printing, October.

SET. (2001b). The determinants of audit committee independence: Evidence from audit committee formation in Thailand. Internet Site: http://www. fma.org/zurich/papers/140140.pdf.

SET. (2003). Good governance assessment of listed companies. Bangkok: Boonsiri Printing.

SET. (2005). Fact book of the SET. Bangkok: Boonsiri Printing.

Suehiro, A. (1989). Capital accumulation in Thailand: 1855 - 1985 (Yuuki Kikaku).

Sureshchandar, G.S., Rajendran, C., \& Anantharaman, R.N. (2002). Determinants of customer - perceived service quality: A confirmatory factor analysis approach. Journal of Services Marketing, 16(1), 9-34. 
Toplin, R., Tower, G., \& Hancock, P. (2002). Disclosure (discernibility) and compliance of accounting policies: Asia-Pacific evidence. Blackwell Synergy: Accounting Forum, 26(2), 172-190.

US SEC (Securities and Exchange Commission). (1992). Executive compensation Disclosure. Release 33-6962, October 16.

Vafeas, N. (1999). Board meeting frequency and firm performance. Journal of Financial Economics, 53(1), 113-142.

Vafeas, N., \& Afxentiou, Z. (1998). The association between the SEC compensation disclosure rule and executive compensation policy changes. Journal of Accounting and Public Policy, 17(1), 27-54.

Vafeas, N., \& Theodorou, E. (1998). The relationship between board structure and firm performance in the U.K. The British Accounting Review, 30, 383407.

Van Der Zahn, M. (2004). Association between board of director characteristics and theamount of voluntary audit committee disclosures. International Journal of Business Governance and Ethics, 1(23), 210-232.

Verrecchia, R.E. (1983). Discretionary disclosure. Journal of Accounting and Economics, 5(3), 179-194.

Verrecchia, R.E. (1990). Information quality and discretionary disclosure. Journal of Accounting and Economics, 12, 365-380.

Wagenhofer, A. (1990). Voluntary disclosure with a strategic opponent. Journal of Accounting and Economics, 12, 341363.
Wallace, R.S.O. (1988). Corporate financial reporting in Nigeria. Accounting and Business Research, 18(72), Autumn, 352-362.

Warfield, T., Wild, J.J., \& Wild, K. (1995). Managerial ownership, accounting choices, and informativeness of earning. Journal of Accounting and Economics, 20, 61-91.

Whidbee, D.A. (1997). Board composition and control of shareholder voting rights in the banking industry. The Journal of the Financial Management Association, 26(4), 27-41.

Willekens, M., Vander Bauwhede, H., Gaeremynck, A., \& Van de Gucht, L. (2004). The impact of internal and external governance mechanisms on the voluntary disclosure of financial and non-financial performance. Working Paper, KULeuven.

Williams, S.M. (2002). Board of director determinants of voluntary audit committee disclosures: Evidence from Singapore. Working paper, Corporate Governance and Intellectual Capital Archive, Singapore Management University, September 19.

Wiwattanakantang, Y. (1999). An empirical study on the determinants of the capital structure of Thai firms. Pacific-Basin Finance Journal, 7, 371-403.

Wiwattanakantang, Y. (2000). The equity ownership structure of Thai firms. Unpublished Working Paper, Institute of Economic Research, Hitotsubashi University, Japan.

Yammeesri, J., \& Lodh, S.C. (2002). The effects of ownership structure on firm performance: Evidence from Thailand. Hawaii International Conference on Business. 